Portland State University

PDXScholar

Civil and Environmental Engineering Faculty

Publications and Presentations

Civil and Environmental Engineering

9-2013

\title{
Transit Bus Fleet Age and Replacement Type Optimization
}

\author{
Miguel A. Figliozzi \\ Portland State University, figliozzi@pdx.edu \\ Wei Feng \\ Portland State University \\ Jesse Boudart \\ Portland State University
}

Follow this and additional works at: https://pdxscholar.library.pdx.edu/cengin_fac

Part of the Civil and Environmental Engineering Commons, and the Transportation Commons Let us know how access to this document benefits you.

\section{Citation Details}

Figliozzi, Miguel A., Wei Feng, and Jesse Boudart. "Transit Bus Fleet Age and Replacement Type Optimization." OTREC-RR-441. Portland, OR: Transportation Research and Education Center (TREC), 2010. https://dx.doi.org/10.15760/trec.106

This Report is brought to you for free and open access. It has been accepted for inclusion in Civil and Environmental Engineering Faculty Publications and Presentations by an authorized administrator of PDXScholar. Please contact us if we can make this document more accessible: pdxscholar@pdx.edu. 


\section{SOTREC}

FINAL REPORT

\section{Transit Bus Fleet Age And Replacement Type Optimization}

OTREC-RR-44 1

September 2013 



\title{
TRANSIT BUS FLEET AGE AND REPLACEMENT TYPE OPTIMIZATION
}

\author{
Final Report
}

\section{OTREC-RR-441}

by

\author{
Miguel Figliozzi, Ph.D. \\ Wei Feng \\ Jesse Boudart
}

Portland State University

for

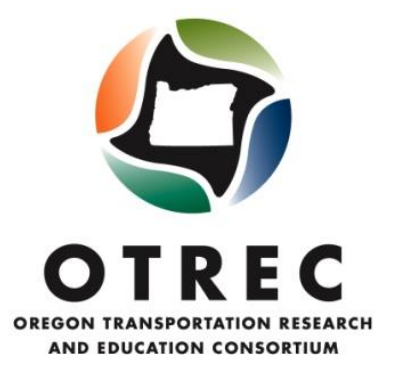

P.O. Box 751

Portland, OR 97207

September 2013 



\section{Technical Report Documentation Page}

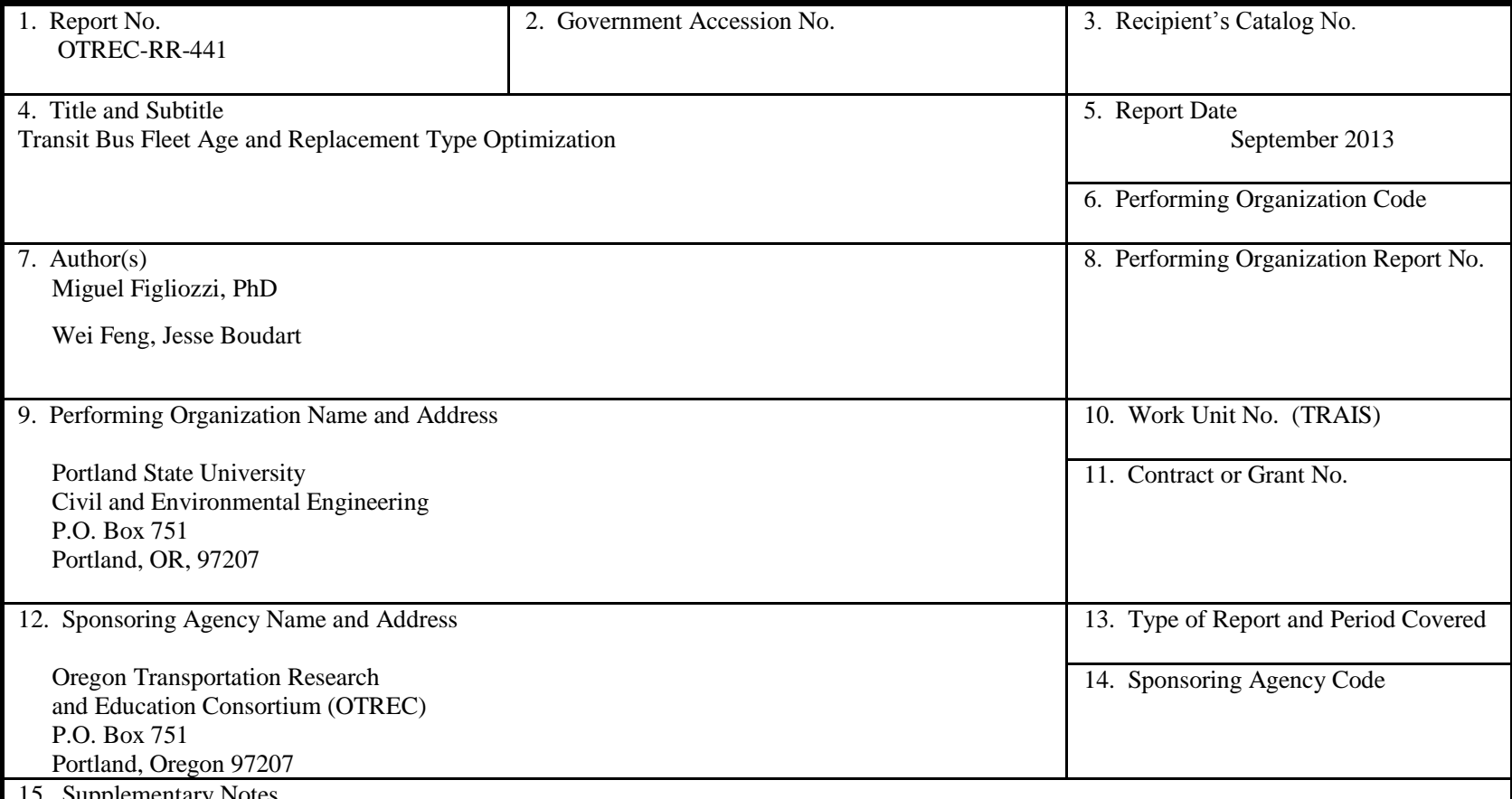

15. Supplementary Notes

\section{Abstract}

Due to recent budget and fiscal constraints, it is ever more imperative for transit agencies to manage their fleets in an optimal way. Fleet data have consistently shown that bus operational and maintenance (O\&M) per-mile costs increase as buses age. From a purely economic perspective, there is a cost tradeoff between the lower O\&M costs of newer fleets and their higher initial capital costs. This tradeoff has a significant impact on the optimal timing of purchase and replacement decisions. Utilizing realistic cost data and an optimization modeling framework, we analyze (a) the impact of purchase timing decisions on fleet per-mile costs and (b) the key factors and variables affecting the optimization of transit diesel and hybrid bus fleets. Given uncertain and hard-to-forecast market variables, multiple scenarios are examined and sensitivity analyses are performed to study the impacts of key variables on optimal replacement policies and costs.

In terms of the impact of purchase timing decisions on fleet per-mile costs (a), results indicate that: 1) increases in diesel prices do not affect total bus fleet costs as much as increases in maintenance costs; 2) increases in maintenance costs and utilization per year reduce the optimal replacement age; 3 ) increases in utilization and fuel economy have a similar impact in terms of total fleet costs; and 4) bus purchase-price changes have a significant impact on the optimal replacement age.

In terms of the key factors and variables affecting the optimization of transit diesel and hybrid bus fleets (b), results indicate that: 1) the Federal Transit Administration (FTA) purchase cost subsidy has the highest impact on the optimal replacement policies; 2) without the FTA subsidy, the optimal policy is to choose the diesel bus unless the purchase cost difference is larger than $10 \%$; 3 ) with an $80 \%$ FTA purchase cost subsidy, the hybrid bus is always the best choice unless fuel economy difference between the hybrid and diesel buses is substantial; 4) maintenance costs affect the optimal replacement age but are unlikely to change the optimal bus type when comparing diesel and hybrid technologies; and 5) greenhouse gas emissions costs are not significant and affect neither bus type nor replacement age.

\begin{tabular}{|c|c|c|c|c|}
\hline \multicolumn{2}{|c|}{$\begin{array}{l}\text { 17. Key Words } \\
\text { Transit, Vehicle Replacement, Bus Technology, Economic Evaluation }\end{array}$} & \multicolumn{3}{|c|}{$\begin{array}{l}\text { 18. Distribution Statement } \\
\text { No restrictions. Copies available from OTREC: } \\
\text { www.otrec.us }\end{array}$} \\
\hline $\begin{array}{l}\text { 19. Security Classification (of this report) } \\
\text { Unclassified }\end{array}$ & $\begin{array}{l}\text { 20. Security Classifi } \\
\text { Unclassified }\end{array}$ & page) & $\begin{array}{l}\text { 21. No. of Pages } \\
43\end{array}$ & 22. Price \\
\hline
\end{tabular}




\section{ACKNOWLEDGEMENTS}

The authors gratefully acknowledge the Oregon Transportation Research and Education Consortium (OTREC) for sponsoring this project. A special acknowledgment goes to Gary Prince and Ralph McQuillan from King County Metro for facilitating access to bus utilization and cost data and their helpful comments. Any errors or omissions are the sole responsibility of the authors.

\section{DISCLAIMER}

The contents of this report reflect the views of the authors, who is solely responsible for the facts and the accuracy of the material and information presented herein. This document is disseminated under the sponsorship of the U.S. Department of Transportation University Transportation Centers Program in the interest of information exchange. The U.S. Government assumes no liability for the contents or use thereof. The contents do not necessarily reflect the

official views of the U.S. Government. This report does not constitute a standard, specification, or regulation. 


\section{TABLE OF CONTENTS}

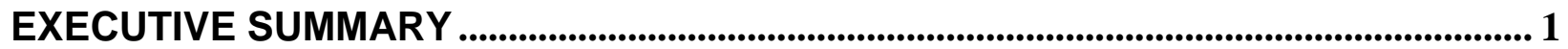

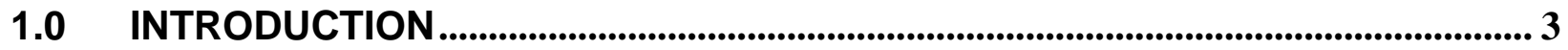

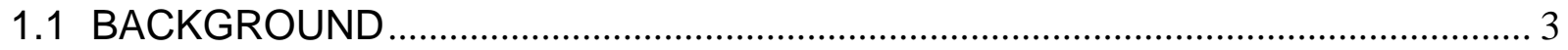

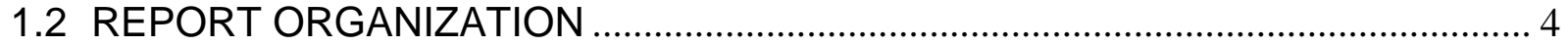

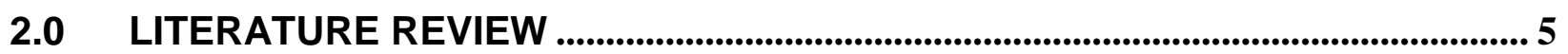

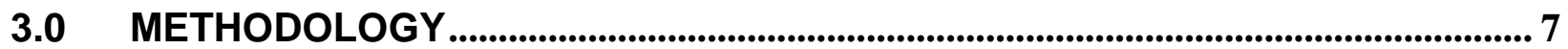

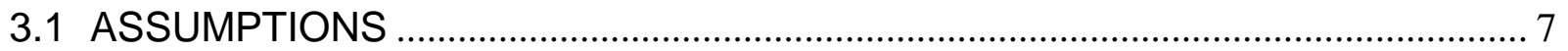

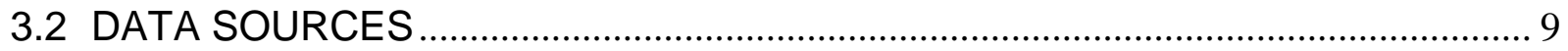

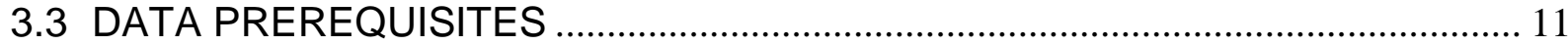

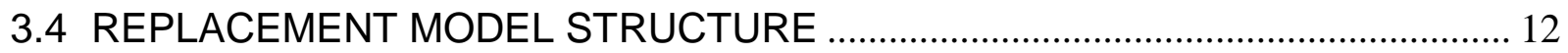

4.0 FLEET REPLACEMENT OPTIMIZATION WITH SINGLE VEHICLE TYPE ....... 13

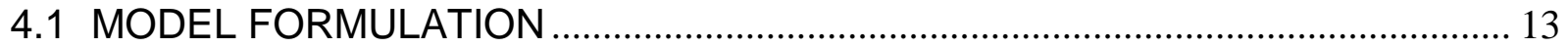

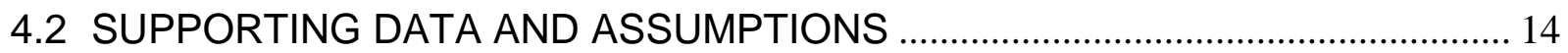

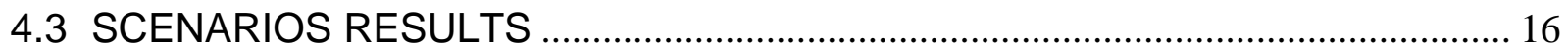

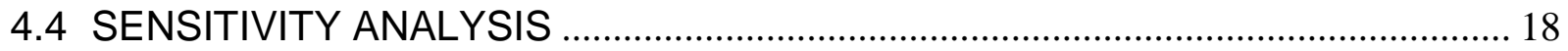

5.0 FLEET REPLACEMENT OPTIMIZATION WITH MULTIPLE VEHICLE TYPES 200

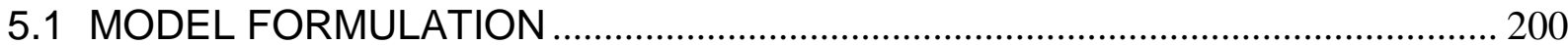

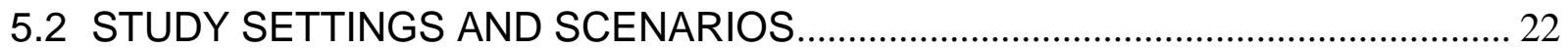

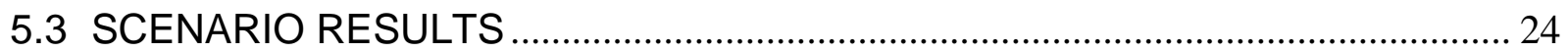

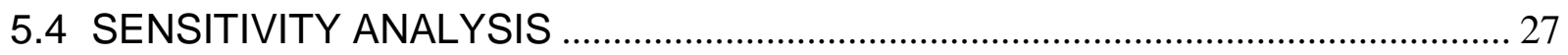

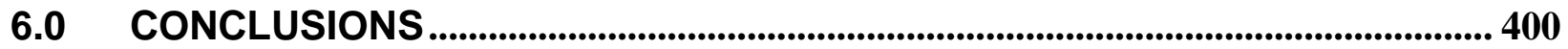

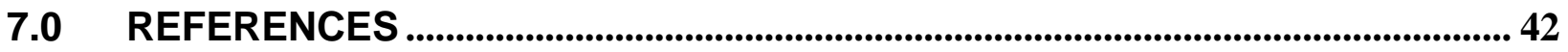




\section{LIST OF TABLES}

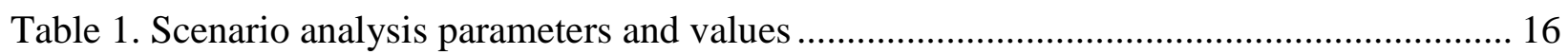

Table 2. Impact of cost increases relative to baseline conditions ............................................. 18

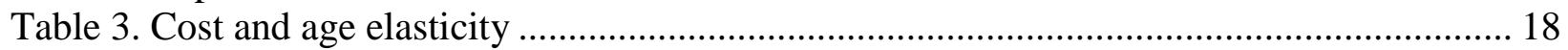

Table 4. Baseline scenario economic factors ................................................................................. 22

Table 5. Baseline scenario vehicular characteristics................................................................ 22

Table 6. Baseline scenarios optimal replacement results (diesel $3.32 \mathrm{mpg}$ and first 20 years) .... 25

Table 7. Baseline scenarios optimal replacement results (diesel $2.5 \mathrm{mpg}$ and first 20 years)...... 26

Table 8. Impacts of diesel bus fuel economy on optimal replacement plan (diesel FE $3.32 \mathrm{mpg}$ )

Table 9. Impacts of diesel bus fuel economy on optimal replacement plan (diesel FE $2.50 \mathrm{mpg}$ )

Table 10. Impacts of annual utilization on optimal replacement plan (diesel FE $3.32 \mathrm{mpg}$ ) ....... 28

Table 11. Impacts of annual utilization on optimal replacement plan (diesel FE $2.50 \mathrm{mpg}$ ) ....... 28

Table 12. Impacts of O\&M cost function slopes (diesel FE $3.32 \mathrm{mpg}$ ) ......................................... 29

Table 13. Impacts of O\&M cost function slopes (diesel FE $2.50 \mathrm{mpg}$ ) .................................. 30

Table 14. Impacts of capital purchase cost on optimal replacement plan (diesel FE $3.32 \mathrm{mpg}$ ).. 31

Table 15. Impacts of capital purchase cost on optimal replacement plan (diesel FE $2.50 \mathrm{mpg}$ ).. 31

Table 16. First 20-year results after including CO2 emissions costs (diesel FE $3.32 \mathrm{mpg}$ ).......... 32

Table 17. First 20-year results after including CO2 emissions costs (diesel FE $2.50 \mathrm{mpg}$ ).......... 33

Table 18. Impacts of initial fleet composition on optimal replacement plan (80\% subsidy) ........ 34

Table 19. Impacts of initial fleet configuration on optimal replacement plan ( $0 \%$ subsidy)........ 34

Table 20. Elasticity between various input variables and per-mile net cost (diesel $3.32 \mathrm{mpg}$ ).... 35

Table 21. Elasticity between various input variables and 20-year NPV (diesel $2.50 \mathrm{mpg}$ ) .......... 36

Table 22. Breakeven values of government subsidies (diesel FE $3.32 \mathrm{mpg}$ ) ……………….......... 37

Table 23. Breakeven values of government subsidies (diesel FE $2.50 \mathrm{mpg}$ ) ................................ 37

Table 24. Breakeven values for 0\% subsidy scenario (diesel FE $3.32 \mathrm{mpg}$ ) ................................ 37

Table 25. Breakeven values for $0 \%$ subsidy scenario (diesel FE $2.50 \mathrm{mpg}$ ) .............................. 38

Table 26. Breakeven values for $80 \%$ subsidy support scenario (diesel FE $3.32 \mathrm{mpg}$ ).................. 38

Table 27. Breakeven values for $80 \%$ subsidy support scenario (diesel FE $2.50 \mathrm{mpg}$ ) .................. 39 


\section{LIST OF FIGURES}

Figure 1. Value of money in future years, 2010 U.S. dollars ................................................ 8

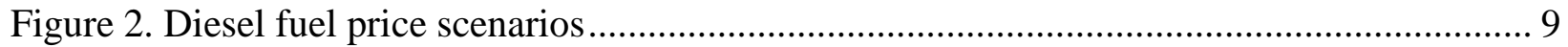

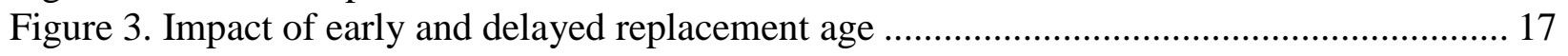

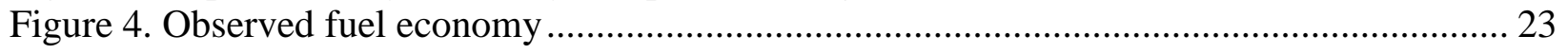

Figure 5. Per-mile O\&M cost functions ........................................................................... 29

Figure 6. Major maintenance cost distributions for 40-foot buses and 35,000 miles per year

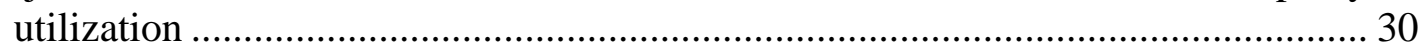

Figure 7. Nonlinear, per-mile, maintenance cost functions ........................................... 31 


\section{EXECUTIVE SUMMARY}

Due to recent budget and fiscal constraints, it is ever more imperative for transit agencies to manage their fleets in an optimal way. Fleet data have consistently shown that bus operational and maintenance $(\mathrm{O} \& \mathrm{M})$ per-mile costs increase as buses age. From a purely economic perspective, there is a cost tradeoff between the lower O\&M costs of newer fleets and their higher initial capital costs. This tradeoff has a significant impact on the optimal timing of purchase and replacement decisions. Utilizing realistic cost data and an optimization modeling framework, we analyze (a) the impact of purchase timing decisions on fleet per-mile costs and (b) the key factors and variables affecting the optimization of transit diesel and hybrid bus fleets.

Given uncertain and hard-to-forecast market variables, multiple scenarios are examined and sensitivity analyses are performed to study the impacts of key variables on optimal replacement policies and costs.

In terms of the impact of purchase timing decisions on fleet per-mile costs (a), results indicate that: 1) increases in diesel prices do not affect total bus fleet costs as much as increases in maintenance costs; 2) increases in maintenance costs and utilization per year reduce the optimal replacement age; 3 ) increases in utilization and fuel economy have a similar impact in terms of total fleet costs; and 4) bus purchase-price changes have a significant impact on the optimal replacement age.

In terms of the key factors and variables affecting the optimization of transit diesel and hybrid bus fleets (b), results indicate that: 1) the Federal Transit Administration (FTA) purchase cost subsidy has the highest impact on the optimal replacement policies; 2) without the FTA subsidy, the optimal policy is to choose the diesel bus unless the purchase cost difference is larger than $10 \%$; 3) with an $80 \%$ FTA purchase cost subsidy, the hybrid bus is always the best choice unless the fuel economy difference between the hybrid and diesel bus is substantial; 4) maintenance costs affect the optimal replacement age but are unlikely to change the optimal bus type when comparing diesel and hybrid technologies; and 5) greenhouse gas emissions costs are not significant and affect neither bus type nor replacement age. 


\subsection{INTRODUCTION}

Transit agencies typically own hundreds or thousands of buses; large transit agencies may have multiple fleets of buses with different types of buses serving different routes. For example, King County transit (KCT) agency in the state of Washington operates about 1,300 vehicles with multiple bus technologies (electric trolley buses, diesel buses, hybrid buses, etc.); designs (60foot articulate, 30-foot or 40-foot standard); and models (New Flyer, Gillig, etc.). Fleet capital, operational and maintenance costs are a significant expense for transit agencies. Due to budget and fiscal constraints, it is ever more imperative for transit agencies to manage their fleets in an optimal way without reducing service quality.

To minimize total fleets costs over a certain time horizon, fleet managers have to consider two important tradeoffs when making replacement decisions. The first tradeoff is related to age; as buses age, the per-mile operating and maintenance (O\&M) costs tend to increase. Replacing old vehicles with new ones reduces these costs but significantly increases capital costs. Therefore, there is an optimal replacement age (lifecycle) that minimizes the total net cost over a planning time horizon. The second tradeoff is related to bus type. Vehicle purchase price and per-mile operating, maintenance and fuel costs vary across bus types (conventional diesel, hybrid, electric trolley, etc.); bus designs; and operating environments (congested or not congested routes, hilly or flat routes). There is an optimal bus type among all the candidates for each transit agency in certain operating environments.

The objective of this research is to utilize real-world data to study (a) the impact of purchase timing decisions on fleet per-mile costs and (b) the key factors and variables affecting the optimization of transit diesel and hybrid bus fleets. This research studies the impacts of government purchase subsidy levels on replacement decisions, and the impact of the remaining input variables and utilization factors.

\subsection{BACKGROUND}

In 2009, King County Transit underwent a follow-up review of a 2007 County Vehicle Replacement performance audit. Recommendations from this follow-up called for the Transit Division to develop its own fleet replacement criteria based on a full-year review of operations and maintenance data for vehicles in the non-revenue fleet ${ }^{1}$. Additionally, in 2009 King County Transit underwent a Performance Audit of Transit to review and evaluate several areas, including trolley bus replacement ${ }^{2}$. This audit revealed that (as of the audit), none of the vehicle fleet replacement criteria was based on economic analysis. Criteria for vehicle replacement ranged from mirroring the FTA's funding guidelines to using professional judgment.

\footnotetext{
${ }^{1}$ See Recommendation 2 in Management Letter from King County Auditor to Metropolitan King County Council members; Subject: Follow-up on Implementation of Recommendations from 2007 Performance Audit of County Vehicle Replacement; dated: November 9, 2009.

${ }^{2}$ See Performance Audit of Transit Summary Report No. 2009-01, dated September 15, 2009.
} 
More recently, a study commissioned by King County evaluated the economic and environmental tradeoffs between electric trolleys and hybrid diesel buses.3 Among the relevant findings contained in this report entitled King County Trolley Bus Evaluation report (herein denoted KCTB report or study) are the following: (a) diesel price forecast has the greatest influence on life-cycle cost results, (b) a change in the vehicle life span for one or both technologies can significantly affect life-cycle costs, and (c) lower discount rates can change replacement costs but not the type of preferred technology.

\subsection{REPORT ORGANIZATION}

This research paper is organized as follows: Section 2 briefly introduces the background of bus fleet replacement practices and replacement optimization models. Section 3 describes the methodology employed, data sources and model structure. Section 4 presents the model and results regarding the impact of purchase timing decisions on fleet per-mile costs. Section 5 presents the model and results regarding the key factors and variables affecting the optimization of transit diesel and hybrid bus fleets. Section 6 ends the report with conclusions.

\footnotetext{
${ }^{3}$ King County Metro. King County Trolley Bus Evaluation. May 2011, http://metro.kingcounty.gov/up/projects/trolleyevaluation.html, http://metro.kingcounty.gov/up/projects/pdf/Metro_TB_20110527_Final_LowRes.pdf
} 


\subsection{LITERATURE REVIEW}

The Management Science and Operations Research literature have pioneered the usage of vehicle replacement models to optimize decisions regarding vehicle purchases, utilization, maintenance, and scrapping. A formal optimization model dealing with machine replacement problems was first introduced in the 1950s (Bellman, 1955). Since then, many researchers have analyzed replacement problems in a wide range of fleet types, including transit and police fleets (Rees et al., 1982; Khasnabis et al., 2003). Some researchers have added budget constraints (Karabakal et al., 1994) and even integrated vehicle-manufacturing waste factors in an automobile life-cycle analysis (Kim et al., 2003). Despite the great uncertainty associated with financial variables and forecasts, all the mentioned models have been deterministic. Furthermore, there has been little or no attention given to sensitivity analysis (Keles et al., 2004).

Previous studies in the public transport field have shown how fuel efficiency and operating and maintenance costs change when vehicles age. Significant differences have been found across bus models, transit agencies and service environments (Lammert 2008; Chandler and Walkowicz 2006; Schiavone 1997). Bus life-cycle costs have been previously compared across bus engine types and design models (Clark et al. 2007; Laver et al. 2007; Clark et al. 2009; Kim et al. 2009). The papers referenced in this paragraph focus on vehicle characteristics and life-cycle costs assuming a constant replacement age. Optimal replacement schedules and bus-type choice that minimize bus fleet total net cost have not been studied.

There is a large body of literature dealing with vehicle replacement optimization models in the operations research field. These models can be broken into two categories depending on whether buses in a fleet are homogeneous or heterogeneous. In homogeneous models, the objective is to find the best bus replacement age for a set of identical vehicles. In other words, buses with the same type and age have to be replaced together (also known as the "no cluster splitting rule"). These models are usually solved using a dynamic programming (DP) approach (Bellman 1955; Oakford, Lohmann, and Salazar 1984; Bean, Lohmann, and Smith 1984; Bean, Lohmann, and Smith 1994; Hartman 2001; Hartman and Murphy 2006). DP has the advantage of allowing the consideration of probabilistic distributions for some state variables, such as utilization or operational costs.

Heterogeneous models are more appropriate when multiple bus fleets have to be optimized simultaneously or when budget constraints are needed. For example, the "no cluster splitting rule" cannot be applied when vehicles of the same type and age may be replaced in different years due to budget limitations. These models are able to solve more practical problems, but input variables are usually deterministic. Stochastic heterogeneous models are difficult to solve. Most heterogeneous models employ integer programming (IP) formulations (Simms et al. 1984; Karabakal, Lohmann, and Bean 1994; Hartman 1999; Hartman 2000; Hartman 2004). With additional assumptions, a DP approach can be applied to heterogeneous problems (Jones, Zydiak, and Hopp 1991). None of the theoretical models mentioned in this paragraph deals with real-world fleet data. 
Several papers have described the use of optimization models to solve real-world problems. Keles and Hartman (2004) adopted an IP model in a transit fleet replacement problem with multiple types of buses. However, many cost functions were highly simplified or not based on real data; a sensitivity analysis based on key vehicle characteristics, utilization levels or market fluctuations were not studied. Fan et al. (2012) developed a fleet optimization framework using a DP approach; however, the simultaneous optimization of heterogeneous vehicles and sensitivity analysis of input variables were not addressed. Figliozzi, Boudart and Feng (2011) and Feng and Figliozzi (2013) adopted IP models to study a fleet of heterogeneous passenger cars and delivery trucks with real-world operational data. Impacts of policy, market, utilization, emissions, and technological factors were analyzed using scenario analysis and elasticity analysis. Boudart and Figliozzi (2012) studied how economic and technological factors affect a single bus optimal replacement age. 


\subsection{METHODOLOGY}

Given that initial capital cost, O\&M and environmental costs vary across vehicle types and over time, it is necessary to find the optimal ownership time that minimizes their sum over a given planning horizon.

The models developed by Portland State University (PSU) will facilitate decision making related to fleet management problems. More specifically, it includes two replacement models to evaluate fleet management decisions regarding vehicle replacement timing for a single vehicle type and vehicle type purchases (e.g., one diesel vs. one hybrid) as well as timing of purchases and scrapping decisions. The corresponding tools ${ }^{4}$ (software) are developed to support analysts' work. Regarding the models, it should be noted that:

- The objective of the models is to minimize the Net Present Value (NPV) associated with vehicle purchases, fuel consumption, operations and maintenance costs, and other costs such as road call costs. $\mathrm{CO}_{2}$ emission costs can also be incorporated into the model. The model selects the bus type and replacement year (or simply replacement year for single vehicle type) that minimize NPV over the chosen planning horizon.

- In the multiple vehicle types model, costs that are the same across vehicles and over time (e.g., driver cost for a hybrid or diesel bus) should not be included in the model since the net NPV savings will not be altered. For example, capital (purchase), fuel and maintenance costs are relevant because hybrid vehicles have an initial cost premium that can be offset over time through incremental annual savings from lower maintenance and/or fuel costs.

- Constraints: The only constraint included in the model is the potential life of a bus. Based on the literature review, two scenarios were tested - 20 years and 30 years. Additionally, if FTA support is used to purchase a vehicle, there is a minimum vehicle life of 12 years.

- The model can use any initial vehicle fleet.

The replacement model is built by using an integer programming model, KCT data, and data from other reports. Two models are developed to find the optimal vehicle replacement age for a single vehicle type, and to find the optimal vehicle type between two candidates and the optimal replacement age. A summary of the methodology and key assumptions follows.

\subsection{ASSUMPTIONS}

The following assumptions are made throughout the report and study:

- To facilitate comparisons with the KCTB study results, it was assumed that a new bus fleet (either diesel or diesel hybrid) buses would enter into service in 2014. All initial capital costs would be incurred starting in 2014 with annual O\&M costs being charged from 2014 onward and discounted to 2010 dollars.

\footnotetext{
${ }^{4} \mathrm{PSU}$ will provide software that runs in any standalone machine (PC or laptop). The software was successfully installed to a KCT laptop during the February 2012 meeting. PSU work does not include installation troubleshooting or issues related to King County computer network or administrative restrictions.
} 
- Because of the uncertainty in predicting some values and costs, such as future fuel prices, maintenance costs and utilization, several scenarios and plausible values were used to test the model and to observe the sensitivity of the model output-to-input variations.

- The annual capital, operating and maintenance expenditures for each vehicle type are summarized in the scenario NPV.

- KCTB study inflation assumptions (future CPI 2.55\%) and a 7\% annual rate (APR) were employed to calculate NPVs. The $9.55 \%$ annual discount rate was specified by King County Executive Policy and includes the cost of money considering time, interest, alternative uses, and risks. The discount rate and fuel prices over time are shown in Figure 1 and 2. The initial fuel prices are the following:

\begin{tabular}{|c|c|}
\hline $\begin{array}{l}\text { Low } \\
\text { fuel } \\
\text { price: }\end{array}$ & $\begin{array}{c}\text { Mid fuel } \\
\text { price: }\end{array}$ \\
\hline \$/gal & \$/gal \\
\hline 2.64 & 3.48 \\
\hline
\end{tabular}

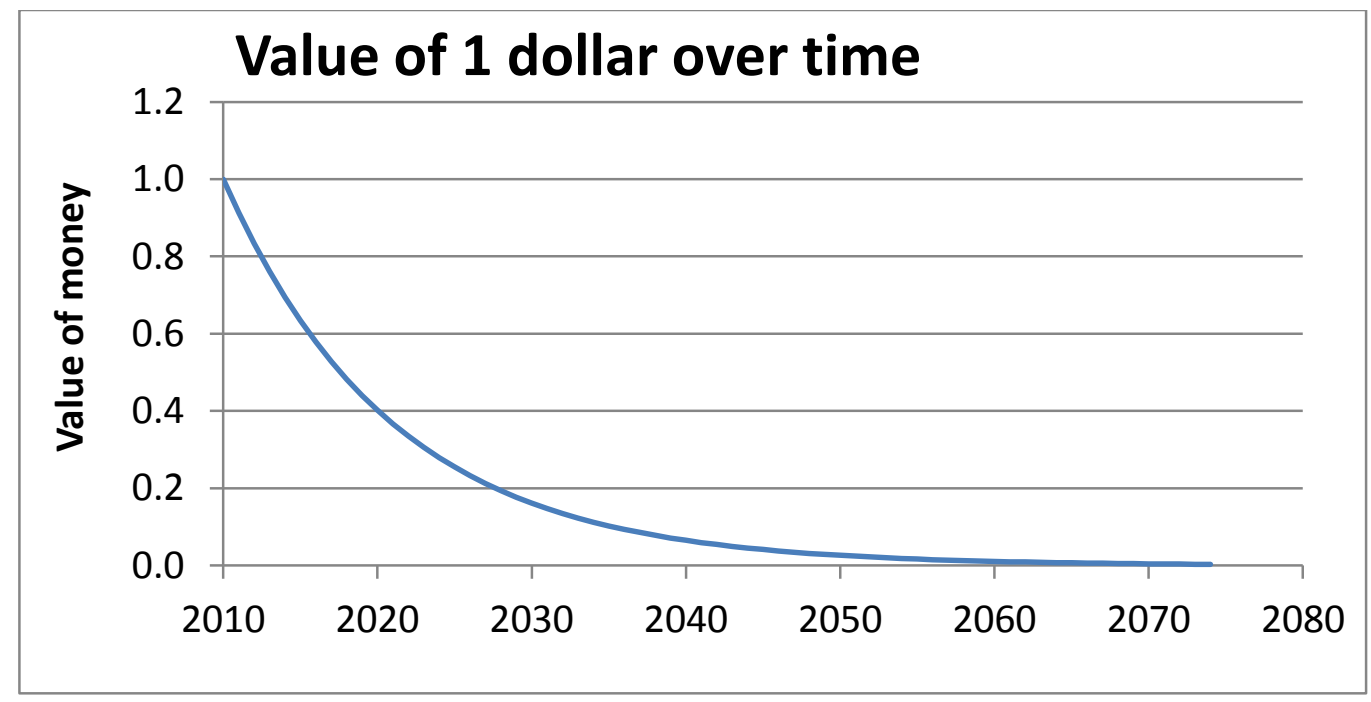

Figure 1. Value of money in future years, 2010 U.S. dollars 


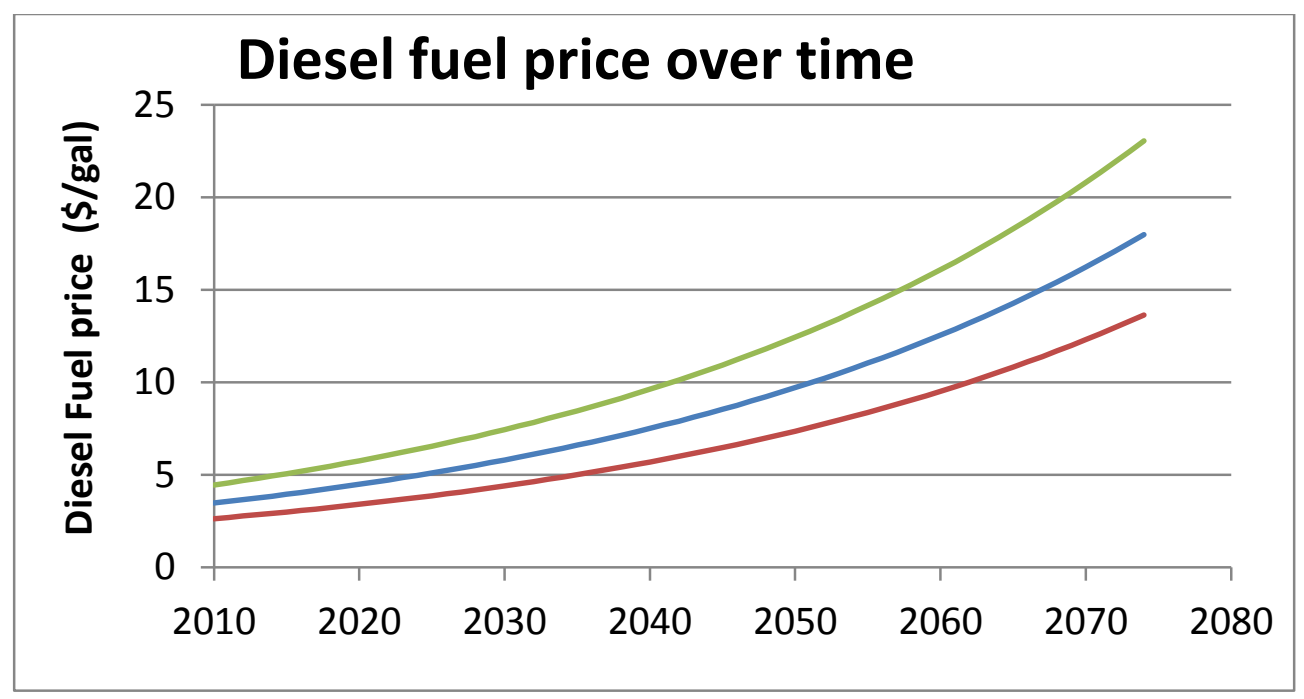

Figure 2. Diesel fuel price scenarios

- The final salvage value per vehicle is assumed to be $\$ 1,000$ (data provided by KCT). Hence, long planning horizons (60 years for single vehicle type model and 100 years for multiple vehicle types model) are chosen to reduce the impact of depreciation and salvage values on the first replacement cycle.

The following additional assumptions are made for the multiple vehicle types model:

- Costs common to both vehicle types, such as driver costs, can be ignored. The focus of the NPV comparisons is to determine the relative cost difference between different vehicle types or replacement ages; the modeled costs are relative rather than absolute.

- The model will correctly indicate the most economical replacement age and bus type; however, the final cost will be greater than estimated within the model because some common costs are excluded.

- It is assumed that buses are being compared in the same route and operating schedule; the only significant differences are fuel efficiency, operations, maintenance, and purchase costs.

- It is assumed that buses of similar passenger capacity and performance are compared.

\subsection{DATA SOURCES}

The data provided by KCT includes disaggregated maintenance cost data (labor, parts and material) by fleet and bus number as well as aggregated annual operational and administrative costs by fleet. Data contained in the KCTB study are used to complete some of the data that are necessary to run the replacement model. The KCTB data do have several advantages: (a) it is recent data that have been provided by KCT and validated by the consultants, and (b) most of the data are directly applicable to KCT buses. 
Although there are published reports that have studied transit vehicle replacement practices and costs, the published costs tend to be general averages that may not be representative of KCT costs (examples are provided in the report). King County Transit owns more than 1,400 buses, vans and trolleys. Approximately $23 \%$ of the fleet is made up of New Flyer and New Flyer hybrid 60-foot buses. These 60 -foot buses were selected for the initial analysis because of the higher number of observations and longer data time series. Data for 60foot buses includes:

- Fleet 23: Detailed maintenance data for 272 New Flyer diesel buses, purchased since 2000 (11 years of available data).

- Fleet 26: Detailed maintenance for 212 New Flyer hybrid diesel buses, purchased since 2004 (seven years of available data).

- Fleet 28: Cost data from a significantly smaller fleet of diesel buses (30 buses) is used to provide an alternative set of diesel maintenance data and fuel economy values.

These are the fleets with the most relevant data and longest time series. The study settings and scenarios sections will state how the data were obtained, especially if the disaggregated maintenance data were employed. KCT has provided aggregated fleet cost data and disaggregated data only for maintenance costs. The aggregated fleet cost data were contained in a series of spreadsheets called "VMCST data;" the data ranges from 1994 to 2009. KCT aggregated data includes annual operations and maintenance costs per bus fleet. The data categories per bus fleet are:

- Age of bus

- Total number of units

- Fuel cost

- Diesel gallons consumed

- Annual miles traveled

- Maintenance costs (mechanics' labor plus parts)

- Tire costs

- Administration costs (management, administrative, etc.)

- General costs (such as facility costs)

- Total costs

From these data categories, useful ratios and performance measures can be created at an aggregated level:

- Total costs per mile

- Miles per gallon (fuel economy)

- Miles per unit

- Maintenance costs per mile

- Total costs per unit

Disaggregated data includes maintenance data, such as date, fleet, unit, repair or task description, labor hours, parts costs, and material costs. 


\subsection{DATA PREREQUISITES}

Potentially, any cost data by mile driven or by age can be incorporated into the models provided by PSU. However, the analyst must feed relevant, high-quality cost and emissions data for each type of vehicle to be analyzed. Data limitations (e.g., disaggregation, format and time-series length) can be easily found if too many categories are included. Furthermore, previously published reports and studies may use simplifying assumptions (linear costs) that may not always be correct. Hence, there is a delicate tradeoff between data quality, number of cost types, and model results quality.

Since the right timing of decisions is a desired outcome, King County Transit should provide quality disaggregated data regarding the impact of vehicle age and history on relevant costs, vehicle performance, and emissions. KCT has only provided aggregated fleet cost data and disaggregated data for maintenance costs.

The replacement model structure is provided in the next page. 


\subsection{REPLACEMENT MODEL STRUCTURE}

Minimizes fleet total costs over a planned time horizon by

Purpose

finding the optimal replacement age and vehicle type.

Provides flexible and convenient input functions (linear or nonlinear) so as to be applicable to as many scenarios as possible for sensitivity and scenario analysis.

Decision When and which existing buses should be replaced with which variables type of new buses over the planning horizon.

Economic factors: planning time horizon, discount rate, utilizations, and energy price forecasts.

Vehicular characteristics: annual utilization, maximal life, Inputs purchase price, salvage value, energy efficiency, and O\&M costs as functions of age.

Fleet initial composition: number, types and ages of initial (existing) fleet vehicles.

Performance measurements:

- Total net cost and cost breakdowns

- Per mile net cost

Outputs

- Optimal new bus candidate

- First/average replacement age

- Fuel consumed

- $\mathrm{CO} 2$ emissions tons and costs

Implementation Uses Excel's format augmented by an optimization package. 


\subsection{FLEET REPLACEMENT OPTIMIZATION WITH SINGLE VEHICLE TYPE}

\subsection{MODEL FORMULATION}

The objective of this model is to minimize bus net costs over the planning horizon, including purchasing, utilization, maintenance, salvage, emissions and road call costs. The decision variable is when to replace buses over the planning horizon.

For the sake of readability and easy interpretation of the model, decision variables or the cardinality of a set are denoted as capital letters; sets are denoted by bold capital letters; and parameters are denoted using small letters, broken down in three categories: constraints, cost or revenue, and emissions.

\section{Indexes}

Age of bus in years: i $\in \boldsymbol{A}=\{0,1,2, \ldots, \mathrm{A}\}$

Time periods, a decision is made at the end of each year: $\mathrm{j} \in \boldsymbol{T}=\{0,1,2, \ldots, \mathrm{T}\}$

\section{Binary Decision Variables}

$X_{i j}=$ the $i$-year old bus in use from the end of year $\mathrm{j}$ to the end of year $\mathrm{j}+1$

$P Y_{j}=$ whether a bus is procured/salvaged at the end of year $j$

\section{Parameters}

(a) Constraints

A = maximum or forced salvage age (the bus must be salvaged if this age is reached)

$\mathrm{u}_{\mathrm{i}} \quad=$ utilization (miles traveled by an i-year old bus)

$\operatorname{mpg}_{\mathrm{i}}=$ fuel economy of $\mathrm{i}$-year old bus

(b) Costs or revenue

$\mathrm{v} \quad=$ cost of purchasing a new bus

$\mathrm{om}_{\mathrm{i}}=$ maintenance costs per mile for an i-year old bus

$\mathrm{rc}_{\mathrm{i}}=$ cost of road calls of an i-year old bus

$\mathrm{s}=$ salvage revenue (negative cost) from selling an old bus when replaced by a new bus

$s f_{\mathrm{iT}}=$ final salvage revenue (negative cost) from selling an i-year old bus at time $\mathrm{T}$

ec $=$ emissions cost per ton of $\mathrm{CO} 2$ emissions

$\mathrm{d}=$ price of diesel fuel per gallon

$\mathrm{dr}=$ discount rate

(c) Emissions

eps $=$ production and salvage emissions, in CO2-tons

$\mathrm{em}_{\mathrm{i}}=$ utilization emissions in CO2-tons per mile for an $i$-year bus 


\section{Objective Function, minimize:}

$\sum_{\mathrm{i}=0}^{\mathrm{A}-1} \sum_{\mathrm{j}=0}^{\mathrm{T}-1} \mathrm{PY} Y_{\mathrm{j}}\left(\mathrm{v}+\mathrm{ec} \cdot \mathrm{eps}-\mathrm{s}-\mathrm{sf}_{\mathrm{iT}}\right)(1+\mathrm{dr})^{-\mathrm{j}}+\sum_{\mathrm{i}=0}^{\mathrm{A}-1} \sum_{\mathrm{j}=0}^{\mathrm{T}-1} \mathrm{X}_{\mathrm{ij}}\left(\mathrm{u}_{\mathrm{i}} \mathrm{om}_{\mathrm{i}}+\mathrm{u}_{\mathrm{i}} \mathrm{mpg}_{\mathrm{i}} \mathrm{d}+\right.$ $\left.\mathrm{u}_{\mathrm{i}} \mathrm{em}_{\mathrm{i}} \mathrm{ec}+\mathrm{rc}_{\mathrm{i}}\right)(1+\mathrm{dr})^{-\mathrm{j}}$

Subject to:

$\mathrm{PY}_{0}=1$, where $\mathrm{s}=0$

$P Y_{\mathrm{T}}=1$, wherev $=0$

$\mathrm{X}_{(\mathrm{i}-1)(\mathrm{j}-1)}=\mathrm{X}_{\mathrm{ij}}+\mathrm{PY}_{\mathrm{j}} \quad \forall \mathrm{i} \in\{1,2, \ldots, \mathrm{A}\}, \forall \mathrm{j} \in\{1,2, \ldots, \mathrm{T}\}$

$P Y_{j}=X_{0 j} \quad \forall j \in\{1,2, \ldots, T-1\}$

$\mathrm{X}_{\mathrm{Aj}}=0 \quad \forall \mathrm{j} \in\{0,1,2, \ldots, \mathrm{T}\}$

$\mathrm{X}_{\mathrm{iT}}=0 \quad \forall \mathrm{j} \in\{0,1,2, \ldots, \mathrm{T}\}$

$P Y_{j}, X_{i j} \in I=\{0,1\}$

The objective function expression (1) minimizes the sum of purchasing, maintenance, salvage, emissions and road call costs over the period of analysis from time zero (present) to the end of the planning horizon (year $T$ ). At the first time period, the model starts with the purchases of a new bus (2). At the end of the last time period (or horizon time $T$ ), the existing bus is sold (3) at a value equal to the salvage value for whatever age the bus has at the time $T, s f_{i T}$. The age of any vehicle in use increases by one year after each time period (4). A constraint makes sure that a bus procured equals a new bus in use (5). When a bus reaches the maximum service age it is forced to be salvaged (6). At the last time period, $T$, the bus is not utilized and operational costs are not added (7). Finally, the decision variables associated to purchasing and salvaging decisions must be binary (8).

\subsection{SUPPORTING DATA AND ASSUMPTIONS}

This section tries to study the impact of various factors that affect the optimal vehicle replacement timing decisions. Therefore, only one vehicle type is considered, which means future purchased new vehicles have to be the same as the type as the existing ones. The input data are supported by the KCTB study. We are modeling a bus that has an average operating cost per mile of $\$ 2.05$ over a 20 -year period.

\section{Maintenance costs}

The total maintenance costs account for labor, parts and tire costs as well as the overhead costs required to maintain the building and employee services. Historically, all maintenance costs have been found to rise with age by approximately $1.5 \%$ per year, while a new bus has the total operating and maintenance costs of $\$ 1.70$ per mile per unit.

\section{Fuel efficiency $\left(\operatorname{mpg}_{i}\right)$}

The average fuel economy of King County diesel buses has been found to be between 2.50 and 3.65 miles per gallon, depending on the route characteristics (topography, number of stops, travel speed, etc.). It is assumed herein that the fuel efficiency is 3.32 miles per gallon according to the KCTB study; this value will be held constant for the life of a vehicle. 


\section{Passengers' road call $(\mathrm{RC})$ costs $\left(\mathrm{rc}_{\boldsymbol{i}}\right)$}

A bus has a "road call" when it has a mechanical problem and a mechanic must be sent out to fix it. Road calls are detrimental to the transit agency because of the additional staff and resources required to repair a bus with mechanical problems. The transit cost of road calls is already integrated in the maintenance cost data. However, previous models have not included passengers' time or inconvenience costs when a bus breaks down. On average, a bus is driven with 8.8 passengers (Davis et al., 2009) and the waiting time associated with road calls is approximately 30minutes in the Seattle metropolitan area (KCMT, 2008). Utilizing a passenger's value of waiting time equal to $\$ 23.67$ per hour, based on the U.S. Department of Transportation (USDOT, 1997) figures and adjusted for inflation (DOL, 2011), the average user cost per road call is $\$ 103.97$ (8.8 passengers). If the bus is loaded with 50 passengers, the cost increases proportionally to $\$ 591.75$ per road call.

\section{Utilization $\left(\boldsymbol{u}_{\boldsymbol{i}}\right)$}

The average utilization of national 60 -foot articulated buses is 31,900 miles per year (Laver et al., 2007), per unit and is held constant for the time horizon of the model.

\section{Salvage Value ( $\left.s \& s f_{i T}\right)$}

Decommissioning a bus is costly because equipment as well as external markings must be removed (KCT, 2011). Additionally, the literature highlights that if revenue from selling a bus exceeds $\$ 5,000$ the difference must be reimbursed to the FTA if FTA's capital assistance funds were employed (FTA, 1992). A salvage value $s=\$ 1,000$ is assumed. However, on year $T$ when the bus is forced to be sold a salvage value of $\$ 1,000$ may not be realistic, especially if a relatively new bus is sold. For the final time period, a linear depreciation function is used to determine the final salvage value based on the initial purchase cost, salvage value, and maximum life of a bus. The final salvage value is determined by the following equation.

$$
s f_{i T}=v-A_{j} *(v-s) / 30
$$

\section{Emissions output and cost (eps, em, ec)}

Life-cycle analysis studies have estimated a passenger vehicle's production and salvage emissions ranging between eight to nine CO2-tons and $13 \mathrm{CO} 2$-tons for sedans and sport utility vehicles (SUV), respectively (Kim et al., 2003; DeCicco and Thomas, 1999; Maclean and Lave, 2003; Samaras and Meisterling, 2008). To the best of the authors' knowledge there is no equivalent bus production and salvage emissions study; a bus $\mathrm{CO} 2$-tons estimation is produced based on a ratio of vehicle weight and the $\mathrm{CO} 2$ released to manufacture and scrap a vehicle. An articulated 60-foot bus weighs 44,000 pounds, whereas a standard sedan and SUV weigh 3,500 and 5,400 pounds, respectively (USA Today, 2011). The emissions associated to the production and salvage of a bus are estimated at 105 tons of $\mathrm{CO} 2$. In addition, there are $\mathrm{CO} 2$ emissions associated with bus usage; this value equals the $\mathrm{CO} 2$ released when a gallon of diesel is burned, which is well known and equals $0.011 \mathrm{CO} 2$-tons (EPA, 2011).

\section{Additional Data Inputs and Assumptions}

On average, transit buses are replaced at year 15.1 and bus ages rarely exceed 30 years (Laver et al., 2007). Hence, the bus maximum age is set to 30 years. A New Flyer 60-foot 
articulated bus is assumed to cost $v=\$ 756,000$ based on what King County pays for its buses, including aftermarket equipment, manuals and contingency.

The FTA provides transit agencies grants for up to $80 \%$ of bus capital purchases (any capital investment) as indicated in US Code Title 49, Subtitle III, Chapter 53, section 5309 (Public Transportation), page 1985: "Based on engineering studies, studies of economic feasibility, and information on the expected use of equipment or facilities, the Secretary shall estimate the net project cost. A grant for the project shall be for 80 percent of the net capital project cost, unless the grant recipient requests a lower grant percentage". When agencies are granted funds, they must adhere to certain FTA guidelines; agencies must keep heavy-duty buses a minimum of 12 years or 500,000 miles, whichever occurs first (Laver et al., 2007). According to a survey of American transit agencies, the average bus retirement age is 15.1 years (Laver et al., 2007). This model will assume that every bus purchase is granted the $80 \%$ subsidy.

Regarding CO2 emissions and climate change effects, there is wide variation in terms of cost per ton. Valuations range from zero (no link between $\mathrm{CO} 2$ and climate change) to $\$ 200 / C O 2-t o n$ or more (Tol, 2005; Stern, 2006). A recent meta-study found that the average social cost of CO2 is \$100/CO2-ton (Peet et al., 2010; Wayne et al., 2009).

Given that some market parameters are highly uncertain or volatile, we provide a set of values for each. Parameters varied in the scenario analysis are presented in Table 1.

Table 1. Scenario analysis parameters and values

\begin{tabular}{ll}
\hline \hline & \multicolumn{1}{c}{ BASELINE } \\
\hline Gasoline Prices $(d)$ & BASELINE or low projected diesel price $=\$ 2.64 /$ gallon, 2011 (33) \\
Emissions Prices $(e c)$ & BASELINE actual emissions price $=\$ 0 /$ CO2-ton \\
O\&M Costs $\left(o m_{i}\right)$ & BASELINE actual O\&M costs $(1)$ \\
Utilization $\left(u_{i}\right)$ & BASELINE flat utilization $u=31,900$ miles $(21)$ \\
FTA's Capital Assistance & BASELINE capital assistance $=80 \%$ \\
User Cost per Road Call & BASELINE equal to zero \\
\hline & \multicolumn{1}{c}{ EXTREME } \\
\hline Gasoline Prices $(d)$ & High projected diesel price $=\$ 4.46 /$ gallon, 2011 (33) \\
Emissions Prices $(e c)$ & High emissions price $=\$ 100 / C O 2-t o n$ from (31) \\
O\&M Costs $\left(o m_{i}\right)$ & High O\&M costs $=25 \%$ increase over the values obtained King County's study \\
\hline & OTHER PARAMETERS ANALYZED INDIVIDUALLY \\
\hline User Cost per Road Call & An average of \$103.97 (8.8 passengers) or high of \$591.75 (full bus) \\
Purchase Costs & Decrease total purchase costs by 10\% \\
\hline \hline
\end{tabular}

\subsection{SCENARIOS RESULTS}

When the model is run under a baseline or average scenario, results show that O\&M, purchase and fuel costs contribute to $63 \%, 15 \%$ and $22 \%$ percent of the bus costs, respectively. In the baseline scenario the optimal replacement age is, on average, 21.5 years. To observe changes in total costs due to budget constraints, the bus purchase/salvage replacement decisions are forced

\footnotetext{
${ }^{5}$ http://www.gpo.gov/fdsys/pkg/USCODE-2008-title49/pdf/USCODE-2008-title49-subtitlellI-chap53-sec5309.pdf
} 
to be two, four and six years before and after the optimal replacement age. The lines in Figure 3 illustrate the percent cost increases over the optimal replacement age.

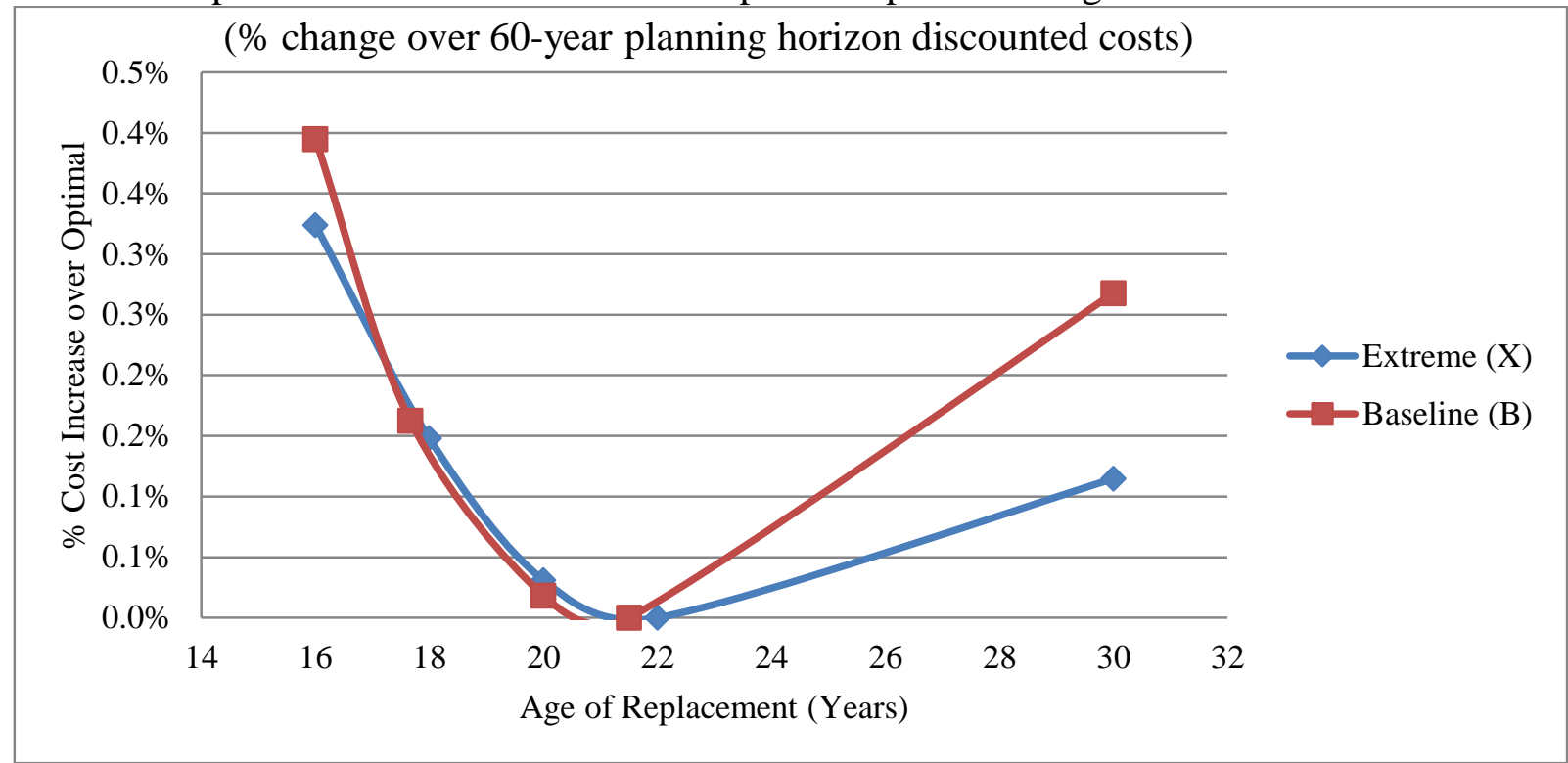

Figure 3. Impact of early and delayed replacement age

Cost changes are relatively small (or flat) around the optimal replacement age. This is in part due to the relatively low increase in O\&M costs. A steeper increase in O\&M costs would lead to optimal replacement ages close to 16 years. In addition, a small change in bus purchase price results in a significant change in optimal replacement age (see Section 6.4, Sensitivity Analysis).

The cost impacts of delaying or hurrying the replacement decisions are not symmetrical. For example, if a replacement decision is delayed to 30 years, the total costs of fleet operation are forecast to increase by $0.1 \%$, whereas if the replacement is advanced to year 16 the total cost increases approximately $0.3 \%$. Budget constraints may force a delayed replacement and this is costly, but not as costly as an early retirement due to maintenance problems or lack of reliability.

If we assume an extreme scenario (high diesel price forecasts, high $\mathrm{CO} 2$ emissions costs of $\$ 100 / \mathrm{CO} 2$-ton, and a $25 \%$ increase in the initial O\&M costs), the optimal replacement age increases from 21.5 to 22 years. Additionally, it is less costly to deviate from the optimal bus replacement age; if a bus is replaced six years before, the cost is forecast to increase by 0.32 and 0.4 percent, respectively, in baseline and extreme scenarios. Early and delayed replacement impacts total fleet emissions in a different manner. By replacing the bus six years earlier than optimal, a total of $1.54 \%$ emissions are increased because the manufacturing emissions cost is incurred more frequently. If a bus is replaced six years later than optimal, the $\mathrm{CO} 2$ decreases by $1.59 \%$. 
Table 2. Impact of cost increases relative to baseline conditions

\begin{tabular}{lcccc}
\hline \hline Cost Category & $\begin{array}{c}\text { High diesel } \\
\text { cost }\end{array}$ & $\begin{array}{c}\text { Emissions } \\
\$ 100 / \mathrm{CO} 2 \text {-ton }\end{array}$ & $\begin{array}{c}\text { O\&M 25\% cost } \\
\text { increase }\end{array}$ & $\begin{array}{c}\text { Purchase cost } \\
10 \% \text { decrease }\end{array}$ \\
\hline Total Cost $(\$)$ & $34.1 \%$ & $10.5 \%$ & $13.5 \%$ & $-1.6 \%$ \\
Purchase Cost $(\$)$ & $0.0 \%$ & $-1.2 \%$ & $4.5 \%$ & $-8.0 \%$ \\
Salvage Revenue $(\$)$ & $0.0 \%$ & $-9.5 \%$ & $25.8 \%$ & $17.7 \%$ \\
Fuel Cost $(\$)$ & $70.1 \%$ & $0.0 \%$ & $0.0 \%$ & $0.0 \%$ \\
O\&M Cost $(\$)$ & $0.0 \%$ & $0.3 \%$ & $19.2 \%$ & $-0.7 \%$ \\
\hline \hline
\end{tabular}

Table 2 shows that the difference between low to high diesel price scenarios increased fuel costs by $70.1 \%$ and total costs by $34.1 \%$. A $25 \%$ increase in O\&M costs per mile increased total O\&M costs $19.2 \%$, total costs by $13.5 \%$ and also affected purchase costs by $4.5 \%$. With higher O\&M costs per mile, it is optimal to replace buses earlier. Imposing an emissions cost from zero to $\$ 100 / \mathrm{CO} 2$-ton increases the total costs by $10.5 \%$, which is less than the high diesel price forecast issued by Linwood Capital (Linwood Capital, 2011). Lastly, decreasing the bus's purchase price decreases total costs by $10 \%$, total purchase costs by $8 \%$, and operating and maintenance costs by $0.7 \%$.

When low and high passenger costs of road calls are integrated into the model, total costs minimally increase by $0.59 \%$ and $3.21 \%$ while the O\&M cost category rises by $0.6 \%$ and $4 \%$. As a separate scenario we also included the transit agency cost of having additional staff on call from increased road calls. However, we found that the extra cost was insignificant and was therefore ignored.

\subsection{SENSITIVITY ANALYSIS}

Finally, we perform a sensitivity analysis to understand what factor has the highest impact on the replacement age. We compute the elasticity of costs to each factor using the following arc elasticity formula (10) where $\eta_{x}^{c}$ is the elasticity of per mile cost $c$ to parameter $x$ :

$$
\eta_{x}^{c}=\frac{\left(x_{1}+x_{2}\right) / 2}{\left(c_{1}+c_{2}\right) / 2} \cdot \frac{\Delta_{c}}{\Delta_{x}}=\frac{\left(x_{1}+x_{2}\right)}{\left(c_{1}+c_{2}\right)} \cdot \frac{\left(c_{2}-c_{1}\right)}{\left(x_{2}-x_{1}\right)}
$$

We also calculate the elasticity of replacement to each parameter assuming a range shown in Table 3 for both types of elasticity (cost per mile and replacement age). For example, if diesel prices increase by $1 \%$ the cost elasticity is 0.17 , meaning that costs per mile increase $0.17 \%$. The replacement age elasticity is 0.00 , meaning that the optimal replacement age was not affected by a gas price increase or increases in fuel economy.

Table 3. Cost and age elasticity

\begin{tabular}{lccccc}
\hline \hline & $\begin{array}{c}\text { Diesel price } \\
\text { low to high } \\
\text { scenario }\end{array}$ & $\begin{array}{c}\text { O\&M } \\
\text { increase }\end{array}$ & $\begin{array}{c}\text { Utilization (miles } \\
\text { per year) } \\
\text { ito } 10 \% \text { increase }\end{array}$ & $\begin{array}{c}\text { Miles per } \\
\text { gallon 0 to } \\
10 \% \text { increase }\end{array}$ & $\begin{array}{c}\text { Purchase cost } \\
0 \text { to } 10 \% \\
\text { increase }\end{array}$ \\
\hline Cost Elasticity & 0.17 & 0.62 & -0.14 & -0.20 & +0.15 \\
Age Elasticity & 0 & -0.75 & -0.82 & 0 & +4.52 \\
\hline \hline
\end{tabular}


Decreasing the purchase price had the most significant impact to decrease the optimal replacement age, which says much about the importance of the $80 \%$ capital cost subsidy. Age elasticity is extremely sensitive to changes in vehicle purchase cost; a $2 \%$ reduction in purchase price can lead to a $9 \%$ (almost 2 years) reduction in optimal replacement age.

Higher utilization will also decrease replacement age as well as higher O\&M costs. As expected, maintenance costs have significant impacts on both costs per mile and replacement age. However, the impact of maintenance costs on replacement age has an opposite sign as expected. Among the remaining variables, fuel efficiency turned out to have lower cost elasticity than utilization. This indicates that improvements in fuel efficiency go a long way in terms of reducing costs per mile and justifying investments in more fuel-efficient buses. 


\subsection{FLEET REPLACEMENT OPTIMIZATION WITH MULTIPLE VEHICLE TYPES}

\subsection{MODEL FORMULATION}

The fleet replacement model described in this section aims to provide answers regarding when and what to purchase/replace or salvage/scrap over time as a function of cost and utilization. The goal is to present a model that is parsimonious yet can evaluate the impacts of new vehicle technologies, operational and maintenance costs, and market conditions.

Indexes

Age of a vehicle type $k$ in years: $i \in \boldsymbol{A}_{\boldsymbol{k}}=\left\{0,1,2, \ldots, A_{k}\right\}$

Time periods, decisions are taken at the end of each year: $j \in \boldsymbol{T}=\{0,1,2, \ldots, T\}$

Type of vehicle/engine: $k \in \boldsymbol{K}=\{1,2, \ldots, K\}$

\section{Decision Variables}

$X_{i j k}=$ the number of $i$-year old, $k$-type vehicles in use from the end of year $j$ to the end of year $j+1$

$Y_{i j k}=$ the number of $i$-year old, $k$-type vehicle salvaged at the end of year $j$

$P_{j k}=$ the number of $k$-type vehicles purchased at the end of year $j$

\section{Parameters}

(a) Constraints

$A_{k}=$ maximum age of vehicle type $k$ (it must be salvaged when a vehicle reaches this age)

$u_{i k}=$ utilization (miles traveled by an $i$-year old, $k$-type vehicle in one year)

$d_{j}=$ demand (miles traveled by all types of vehicle) from the end of year $j$ to the end of year $j+1$

$b_{j}=$ budget (available for purchasing new vehicles) constraint from the end of year $j$

(b) Costs or revenue

$v_{k} \quad=$ purchase cost of a $k$-type vehicle

$f_{i k}=$ fuel economy (mpg) for an $i$-year old, $k$-type vehicle

$f c_{j}=$ fuel price (\$/gallon) in year $j$

$o m_{i k}=$ operation and maintenance costs per mile for an $i$-year old, $k$-type vehicle

$s_{i k}=$ salvage revenue (negative cost) from selling an $i$-old, $k$-type vehicle

ec $=$ emissions cost per ton of $\mathrm{GHG}$

$d r_{j} \quad=$ discount rate of year $j$

(c) Emissions

$e p_{k}=$ production emissions, in GHG equivalent tons, associated to a $k$-type vehicle

$e m_{i k}=$ utilization emissions in GHG equivalent tons per mile for an $i$-year old, $k$-type vehicle

(d) Initial conditions

$h_{i k}=$ the number of $i$-year old, $k$-type vehicles available at the beginning 


\section{Objective Function, minimize:}

$\sum_{j=0}^{T-1} \sum_{k=1}^{K}\left(v_{j k}+e p_{k} e c\right) P_{j k}\left(1+d r_{j}\right)^{-j}+\sum_{i=0}^{N_{k}-1} \sum_{j=0}^{T-1} \sum_{k=1}^{K}\left(\frac{f c_{j} u_{i k}}{f_{i k}}\right) X_{i j k}\left(1+d r_{j}\right)^{-j}+$

$\sum_{i=0}^{N_{k}-1} \sum_{j=0}^{T-1} \sum_{k=1}^{K} \mathrm{om}_{i k} u_{i k} X_{i j k}\left(1+d r_{j}\right)^{-j}-\sum_{i=1}^{N_{k}} \sum_{j=0}^{T} \sum_{k=1}^{K} s_{i k} Y_{i j k}\left(1+d r_{j}\right)^{-j}+$

$\sum_{i=0}^{N_{k}-1} \sum_{j=0}^{T-1} \sum_{k=1}^{K} e m_{i k} u_{i k} e c X_{i j k}\left(1+d r_{j}\right)^{-j}$

Subject to:

$\sum_{k=1}^{K} v_{j k} \cdot P_{j k} \geq b_{j} \forall j \in\{0,1,2, \mathrm{o}: \mathrm{u} T-1\}$

$\sum_{i=0}^{N_{k}-1} \sum_{k=1}^{K} X_{i j k} \cdot u_{i k} \geq d_{j} \forall j \in\{0,1,2, \mathrm{o}: \mathrm{u} T-1\}$

$P_{j k}=X_{0 j k} \forall j \in\{1,2,2, T-1\} \forall k \in \mathbf{K}$

$P_{0 k}+h_{0 k}=X_{00 k} \forall k \in \mathbf{K}$

$X_{i 0 k}+Y_{i 0 k}=h_{i k} \forall i \in\left\{1,2,2, A_{k}\right\}, \forall k \in \mathbf{K}$

$X_{(i-1)(j-1) k}=X_{i j k}+Y_{i j k} \forall i \in\left\{1,2,2, A_{k}\right\}, 2 j \in\{1,2,2, T\}, 2 k \in \mathbf{K}$

$X_{i T k}=0 \quad i \in\left\{0,1,2, \mathrm{o}: \mathrm{u} A_{k}-1\right\} \forall k \in \mathbf{K}$

$X_{A_{k} j k}=0 \quad j \in\{0,1,2, \mathrm{o}: \mathrm{u} T\} \quad \forall k \in \mathbf{K}$

$Y_{0 j k}=0 \quad j \in\{0,1,2, \ldots, T\} \quad \forall k \in \mathbf{K}$

$P_{j k}, X_{i j k}, Y_{i j k} \in \mathbf{I}=\{0,1,2, \ldots\}$

The objective function, expression (11), minimizes the sum of purchasing, energy (fuel) cost, O\&M costs, salvage, and emissions costs over the period of analysis (i.e., from time zero (present) to the end of year T). Purchase costs cannot exceed the yearly budget, expression (12). The number of vehicles in the fleet at any time must equal or exceed the minimum needed to cover the demand in terms of annual number of buses or annual miles traveled, expression (13). The number of vehicles purchased must equal the number of new vehicles for each vehicle type and year, except for the current time, expression (14). The number of new vehicles utilized during year zero must equal the sum of existing new vehicles plus purchased vehicles, expression (15). Similarly, expression (16) ensures the conservation of vehicles (i.e., the initial vehicles - not 0-age ones - must be either used or sold). The age of any vehicle in use will increase by 1 year after each time period (17). At the end of the last time period, there will be no vehicle in use for any age or type of vehicles (i.e., all vehicles will be sold at the corresponding salvage value, which is a function of vehicle type and age) (18). When a vehicle reaches its allowable maximum age, a function of vehicle type, the vehicle must be sold at the corresponding salvage value (19). A newly purchased vehicle should not be sold before use (20). Finally, the decision variables associated with purchasing, utilization and salvaging decisions must be integer positive numbers, expression (21). 


\subsection{STUDY SETTINGS AND SCENARIOS}

Although the model is able to provide the optimal solution for any given set of inputs, the uncertainty associated with the future value of some factors (e.g., fuel prices and maintenance costs) requires several scenarios to be run and studied. All scenarios are based on the analysis of 60 -foot diesel and hybrid buses. The scenarios are also employed to highlight the application of the model and key results obtained.

The baseline scenario economic factors are summarized in Table 4. A long planning time horizon of 100 years $(T=100)$ was used to remove the effect of the last incomplete vehicle life cycle and final resale value on average vehicle replacement age. Emissions costs are not considered in the baseline scenarios but will be analyzed in Section 5.4, Sensitivity Analysis.

Table 4. Baseline scenario economic factors

\begin{tabular}{cccccccc}
\hline \hline \multirow{2}{*}{$\begin{array}{c}\text { Planning } \\
\text { horizon }\end{array}$} & $\begin{array}{c}\text { Nominal } \\
\text { annual } \\
\text { discount rate }\end{array}$ & \multicolumn{2}{c}{$\begin{array}{c}\text { Base Fuel price } \\
(\$ / \text { gal })\end{array}$} & & $\begin{array}{c}\text { Fuel } \\
\text { inflation } \\
\text { rate }\end{array}$ & $\begin{array}{c}\text { Emission } \\
\text { cost } \\
(\$ / \text { ton })\end{array}$ & $\begin{array}{c}\text { Budget } \\
\text { constraint }\end{array}$ \\
\cline { 3 - 4 } $\begin{array}{c}100 \\
\text { years }\end{array}$ & $9.55 \%$ & 2.64 & 3.48 & 4.46 & $2.6 \%$ & 0 & $\begin{array}{c}\text { No } \\
\text { constraint }\end{array}$ \\
\hline \hline
\end{tabular}

For simplicity in reporting and comparing results, in this paper only two bus technologies (types) are selected to replace existing buses: New Flyer 60-foot hybrid diesel bus $(k=1)$ and New Flyer 60 -foot conventional diesel bus $(k=2)$. There are no budget constraints and detailed vehicular characteristics of the two bus types are summarized in Table 5.

Table 5. Baseline scenario vehicular characteristics

\begin{tabular}{|c|c|c|c|c|c|c|c|c|}
\hline $\begin{array}{c}\text { Bus } \\
\text { type } \\
\text { inde } \\
\mathrm{x} \\
\end{array}$ & $\begin{array}{l}\text { Bus } \\
\text { type }\end{array}$ & $\begin{array}{c}\text { Max } \\
\text { age } \\
\text { (years) }\end{array}$ & $\begin{array}{c}\text { Purchase } \\
\text { cost }(\$)\end{array}$ & $\begin{array}{c}\text { Salvage } \\
\text { value }(\$) \\
i=\text { age }\end{array}$ & $\begin{array}{l}\text { Annual } \\
\text { utilization } \\
\text { (miles) }\end{array}$ & $\begin{array}{l}\text { Fuel economy } \\
\text { (mpg) }\end{array}$ & $\begin{array}{l}\text { Per-mile } \\
\text { O\&M costs } \\
\text { (\$/mile) }\end{array}$ & $\begin{array}{c}\text { Tailpipe } \\
\text { emissions } \\
\text { (kg/mile) }\end{array}$ \\
\hline $\begin{array}{l}k \\
=1\end{array}$ & Hybrid & $\begin{array}{l}A_{1} \\
=20\end{array}$ & $\begin{array}{l}v_{1} \\
=958,000\end{array}$ & $\begin{array}{l}s_{i 1} \\
=1000\end{array}$ & $\begin{array}{l}u_{i 1} \\
=33,045\end{array}$ & $f_{i 1}=3.65$ & $\begin{array}{l}\mathrm{om}_{i 1}= \\
1.458 \\
+0.0661 \cdot i\end{array}$ & $\begin{array}{l}e m_{i 1} \\
=2.504\end{array}$ \\
\hline $\begin{array}{l}k \\
=2\end{array}$ & Diesel & $\begin{array}{l}A_{2} \\
=20\end{array}$ & $\begin{array}{l}v_{2} \\
=737,000\end{array}$ & $\begin{array}{l}s_{i 2} \\
=1000\end{array}$ & $\begin{array}{l}u_{i 2} \\
=33,045\end{array}$ & $\begin{array}{c}f_{i 2}= \\
2.50 \text { or } 3.32\end{array}$ & $\begin{array}{l}o m_{i 2}= \\
1.706 \\
+0.0463 \cdot i\end{array}$ & $\begin{array}{l}e m_{i 2} \\
=3.407\end{array}$ \\
\hline
\end{tabular}

Utilization data from King County Metro indicate that the hybrid bus fuel economy (FE) is $3.65 \mathrm{mpg}$ and the diesel bus FE can range from $2.50 \mathrm{mpg}$ to $3.50 \mathrm{mpg}$ on average (see Figure 4). From the data it is not possible to tell the route where buses are operated or the amount of rotation among routes. In general, fuel economy does not significantly vary with age, therefore, $\mathrm{f}_{\mathrm{i} 1}=3.65 \mathrm{mpg}$ for the hybrid and for the diesel bus two FE values are assumed: $f_{i 2}=$ $2.50 \mathrm{mpg}$ (fleet \#28) and $f_{i 2}=3.32 \mathrm{mpg}$ (fleet \#23).

The maximum age is assumed to be 20 years for both buses $\left(A_{1}=A_{2}=20\right)$, because most transit agencies in the U.S. replace their buses in less than the 20 -year cycle (Laver et al., 2007). The purchase costs for the two buses are $v_{1}=\$ 958,000$ for hybrid bus and $v_{2}=$ $\$ 737,000$ for diesel bus, ordering costs and other related costs already included. Also, transit agencies can receive purchase subsidies from the FTA with additional stipulations that must be 
met. For example, if an $80 \%$ purchase cost subsidy is received the bus must be kept for a minimum of 12 years. The salvage values for the two buses are assumed to be $\$ 1,000$ regardless of bus type or age according to King County Metro's request $\left(s_{i k}=\$ 1,000, \forall i \in\left\{1,2, \ldots, A_{k}\right\}\right.$, $\forall k \in \boldsymbol{K})$.

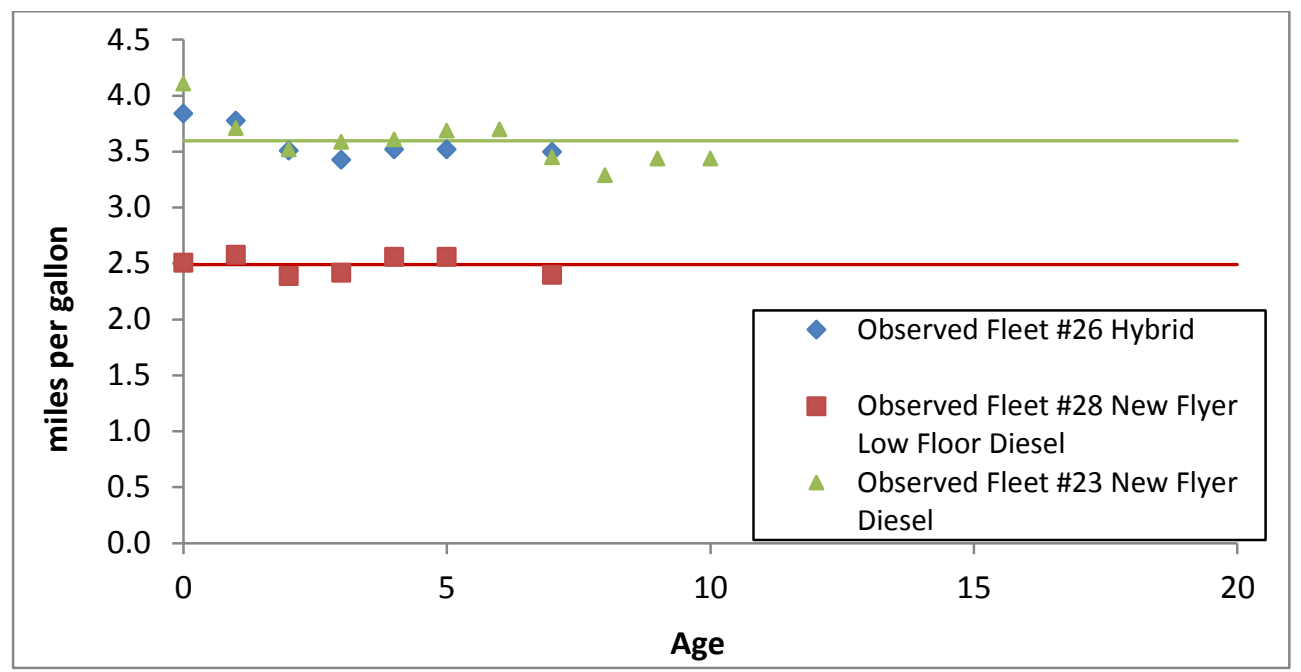

Figure 4. Observed fuel economy

Because the two competing buses are going to serve the same bus routes, their annual utilizations (miles traveled) have to be equal, and this annual utilization does not vary with bus age $\left(\mathrm{u}_{\mathrm{ik}}=33,045 \mathrm{miles} / \mathrm{year}\right.$ according to current fleet data, $\left.\forall i \in\left\{0,1,2, \ldots, A_{k}-1\right\}, \forall k \in \boldsymbol{K}\right)$. The per-mile O\&M costs for the two bus types vary significantly. The baseline scenario uses the per-mile O\&M cost functions estimated by King County Metro (2011), om o $_{i 1}=1.4580+$ $0.0661 \times i ;$ om $_{i 2}=1.7060+0.0463 \times i, \forall i \in\left\{0,1,2, \ldots, A_{k}-1\right\}$. Other O\&M cost functions will be tested in the Sensitivity Analysis section. Only the tailpipe CO2 emissions are considered in the model, and the generation rates are $2.504 \mathrm{~kg} / \mathrm{mile}$ for hybrid buses and $3.407 \mathrm{~kg} / \mathrm{mile}$ for diesel buses, according to Clark et al. (2007). Therefore, $e m_{i 1}=2.504 \mathrm{~kg} / \mathrm{mi}, \mathrm{em}_{i 2}=$ $3.407 \mathrm{~kg} / \mathrm{mi}, \forall i \in A_{k}$.

\section{Initial fleet Composition}

It is assumed that in 2014 the existing buses will be replaced with new ones. Therefore, these buses will be salvaged for certain by 2014, and their replacement cycles are not decision variables anymore. The initial fleet composition in year 2014 is equivalent to no initial buses $\left(h_{i k}=0, \forall i \in\left\{0,1,2, \ldots, A_{k}-1\right\}, \forall k \in \boldsymbol{K}\right)$.

\section{Key Research Questions}

If it is assumed that in 2014 the existing buses will be replaced with new ones, the problem thus becomes: Should King County Metro buy a 60-foot hybrid bus or a conventional 60 -foot diesel bus? What will be the optimal replacement cycle? Also, because King County Metro assumes a homogeneous bus fleet and no budget constraints, a group of buses that are purchased together have to be used and salvaged together. Therefore, instead of optimizing for the actual number of buses in a fleet, a constant number of buses is set to one $\left(d_{j}=1, \forall j \in\right.$ $\{0,1,2, \ldots, T-1\})$, and results are presented on a per-bus basis. 


\subsection{SCENARIO RESULTS}

\section{Baseline scenario results}

The baseline scenarios include 12 scenarios: three fuel price functions, two levels of subsidies ( $0 \%$ and $80 \%$ ), and two diesel bus FE (3.32 and $2.50 \mathrm{mpg}$ ); all other parameters are kept constant. The optimal replacement solutions for each of the six baseline scenarios are summarized and shown in Table 6 and Table 7, respectively, for diesel fuel efficiency 3.32 and $2.50 \mathrm{mpg}$.

The five cost components and their sum (total cost) are shown explicitly as annual costs (average over the first 20 years) with both discounted annualized costs and not-discounted annualized costs; the discounted and not-discounted per-mile costs are also shown. Note that the discounted annualized costs are much smaller than the not-discounted costs due to the impact of the discount rate. Also, the percentage-cost breakdown of the five cost components is different between discounted and not-discounted annualized costs because of the different timing and combined effects of discount rate, fuel inflation rate and planning time horizon. The optimal solutions are to minimize the total discounted sum of all the cost components (minimize net present value). The optimal replacement decisions are shown in the first rows.

If no purchase cost subsidy is received, the optimal solution is to purchase diesel buses and replace them every 20 years (maximum age) with the exception of high fuel costs and low diesel fuel efficiency. If an $80 \%$ purchase cost subsidy can be received, the optimal solution switched to purchasing hybrid buses and replacing them every 16 years in all cases. These results indicate that government subsidy levels affect the optimal replacement solution significantly. This is because when no subsidy is received, purchase cost dominates other cost components. The savings from lower fuel costs and O\&M costs cannot compensate for the high purchase cost of a hybrid bus. On the other hand, if an $80 \%$ purchase subsidy is received, the purchase cost drops significantly and savings in fuel cost and O\&M costs from choosing hybrid buses outweigh their higher purchase cost. The subsidy affects the optimal replacement age in a similar way. A low subsidy tends to extend the optimal replacement age whereas low capital cost tends to shorten the replacement cycle. These results also show that fuel price has no effect on the optimal replacement solutions unless there is an scenario that combines low diesel fuel efficiency and high fuel prices. The reduction in $\mathrm{CO} 2$ emissions is proportional to the reduction in fuel consumption. 
Table 6. Baseline scenarios optimal replacement results (diesel $3.32 \mathrm{mpg}$ and first 20 years)

\begin{tabular}{|c|c|c|c|c|c|c|}
\hline Purchase subsidy & \multicolumn{3}{|c|}{$0 \%$} & \multicolumn{3}{|c|}{$80 \%$} \\
\hline Fuel price & Low & Mid & High & Low & Mid & High \\
\hline Optimal Bus Type & Diesel & Diesel & Diesel & Hybrid & Hybrid & Hybrid \\
\hline Hybrid replacement age & - & - & - & 16 & 16 & 16 \\
\hline Diesel replacement age & 20 & 20 & 20 & - & - & - \\
\hline Discounted annualized costs & & & & & & \\
\hline Total $\operatorname{cost}(\$)$ & 83,969 & 88,782 & 94,397 & 54,263 & 58,641 & 63,748 \\
\hline Purchase $\operatorname{cost}(\$)$ & 36,850 & 36,850 & 36,850 & 11,806 & 11,806 & 11,806 \\
\hline Fuel $\operatorname{cost}(\$)$ & 15,126 & 19,939 & 25,555 & 13,759 & 18,137 & 23,244 \\
\hline$O \& M \operatorname{cost}(\$)$ & 31,992 & 31,992 & 31,992 & 28,710 & 28,710 & 28,710 \\
\hline $\mathrm{CO} 2 \operatorname{cost}(\$)$ & 0 & 0 & 0 & 0 & 0 & 0 \\
\hline Salvage revenue $(\$)$ & 0 & 0 & 0 & -12 & -12 & -12 \\
\hline Per-mile discounted cost $(\$ /$ mile $)$ & 2.541 & 2.687 & 2.857 & 1.642 & 1.775 & 1.929 \\
\hline Not-discounted ann & & & & & & \\
\hline Total $\operatorname{cost}(\$)$ & 141,666 & 152,453 & 165,037 & 111,889 & 121,701 & 133,148 \\
\hline Purchase $\operatorname{cost}(\$)$ & 36,850 & 36,850 & 36,850 & 19,160 & 19,160 & 19,160 \\
\hline Fuel $\operatorname{cost}(\$)$ & 33,901 & 44,688 & 57,273 & 30,836 & 40,648 & 52,095 \\
\hline$O \& M \operatorname{cost}(\$)$ & 70,915 & 70,915 & 70,915 & 61,943 & 61,943 & 61,943 \\
\hline $\mathrm{CO} 2 \operatorname{cost}(\$)$ & 0 & 0 & 0 & 0 & 0 & 0 \\
\hline Salvage revenue $(\$)$ & 0 & 0 & 0 & -50 & -50 & -50 \\
\hline Not-discounted per-mile cost $(\$ /$ mile $)$ & 4.287 & 4.613 & 4.994 & 3.386 & 3.683 & 4.029 \\
\hline Annual fuel (gallons) & 9,953 & 9,953 & 9,953 & 9,053 & 9,053 & 9,053 \\
\hline Annual CO2 (tons) & 110 & 110 & 110 & 100 & 100 & 100 \\
\hline Annual miles & 33,045 & 33,045 & 33,045 & 33,045 & 33,045 & 33,045 \\
\hline
\end{tabular}


Table 7. Baseline scenarios optimal replacement results (diesel $2.5 \mathrm{mpg}$ and first 20 years)

\begin{tabular}{l|rrr|rrr}
\hline \hline Purchase subsidy & \multicolumn{3}{|c|}{$0 \%$} & \multicolumn{3}{c}{$80 \%$} \\
\hline Fuel price & Low & Mid & High & Low & Mid & High \\
\hline Optimal Bus Type & Diesel & Diesel & Hybrid & Hybrid & Hybrid & Hybrid \\
Hybrid replacement age & - & - & 20 & 16 & 16 & 16 \\
Diesel replacement age & 20 & 20 & - & - & - & - \\
\hline Discounted annualized costs & & & & & & \\
Total cost $(\$)$ & 88,930 & 95,322 & 101,278 & 54,263 & 58,641 & 63,748 \\
Purchase cost $(\$)$ & 36,850 & 36,850 & 47,900 & 11,806 & 11,806 & 11,806 \\
Fuel cost $(\$)$ & 20,088 & 26,480 & 23,244 & 13,759 & 18,137 & 23,244 \\
O\&M cost $(\$)$ & 31,992 & 31,992 & 30,134 & 28,710 & 28,710 & 28,710 \\
CO2 cost $(\$)$ & 0 & 0 & 0 & 0 & 0 & 0 \\
Salvage revenue(\$) & 0 & 0 & 0 & -12 & -12 & -12 \\
\hline Per-mile discounted cost $(\$ / m i l e)$ & 2.691 & 2.885 & 3.065 & 1.642 & 1.775 & 1.929 \\
\hline Not-discounted annualized costs & & & & & & \\
Total cost $(\$)$ & 152,786 & 167,111 & 168,927 & 111,889 & 121,701 & 133,148 \\
Purchase cost(\$) & 36,850 & 36,850 & 47,900 & 19,160 & 19,160 & 19,160 \\
Fuel cost $(\$)$ & 45,021 & 59,346 & 52,095 & 30,836 & 40,648 & 52,095 \\
O\&M cost $(\$)$ & 70,915 & 70,915 & 68,932 & 61,943 & 61,943 & 61,943 \\
CO2 cost $(\$)$ & 0 & 0 & 0 & 0 & 0 & 0 \\
Salvage revenue(\$) & 0 & 0 & 0 & -50 & -50 & -50 \\
\hline Not-discounted per-mile cost $(\$ / m i l e)$ & 4.624 & 5.057 & 5.112 & 3.386 & 3.683 & 4.029 \\
\hline Annual fuel (gallons) & 13,218 & 13,218 & 9,053 & 9,053 & 9,053 & 9,053 \\
Annual CO2 (tons) & 147 & 147 & 147 & 100 & 100 & 100 \\
Annual miles & 33,045 & 33,045 & 33,045 & 33,045 & 33,045 & 33,045 \\
\hline
\end{tabular}




\subsection{SENSITIVITY ANALYSIS}

Although the model is able to provide the optimal solution given a set of input variables, the variability and uncertainty of the input variables requires additional sensitivity analysis to understand how optimal solutions are affected by changes in each of the input variables. Holding input variables in the baseline scenarios constant, we evaluate the effects of each input variable on the optimal replacement solution: optimal choice of bus type and replacement age, as well as per-mile net cost, respectively. Only the medium fuel price was used in this sensitivity analysis.

\section{Fuel economy}

According to the data provided by King County Metro, the 60-foot New Flyer hybrid bus fuel economy varies slightly between $3.50 \mathrm{mpg}$ and $3.75 \mathrm{mpg}$. However, the 60 -foot New Flyer diesel bus fuel economy varies significantly between $2.40 \mathrm{mpg}$ and $3.40 \mathrm{mpg}$; the high fuel efficiency is achieved in some routes with favorable conditions such as flat terrain and less congestion or stops. Therefore, to investigate the impact of relative fuel economies between diesel and hybrid buses, different fuel economies for both diesel and hybrid buses were tested within ranges that cover the observed fuel economy records. Sensitivity results are summarized in Table 8 and Table 9. Diesel bus fuel economy ranges from $2.0 \mathrm{mpg}$ to $3.0 \mathrm{mpg}$ with $0.1 \mathrm{mpg}$ interval. Hybrid bus fuel economy ranges from $3.15 \mathrm{mpg}$ to $4.15 \mathrm{mpg}$ with $0.1 \mathrm{mpg}$ interval.

Table 8 and Table 9 show how optimal replacement solutions change with varying diesel and hybrid bus fuel economies in both $0 \%$ and $80 \%$ subsidy scenarios. The "number+letter" in the table indicates what replacement age and bus type is optimal. For example, "16H" indicates that the optimal solution is to choose a hybrid bus and replace it every 16 years. It is noticeable that in all cases the replacement ages do not change considerably although the bus type can change. There is a frontier or combination of low hybrid fuel efficiency and high diesel fuel efficiency where the optimal bus type changes (and vice versa). For example, if diesel fuel efficiency is lower than 2.4 miles per gallon then hybrids are always the best option $(0 \%$ subsidy level); if hybrid fuel efficiency is higher than 3.45 miles per gallon then hybrids are always the best option ( $80 \%$ subsidy level).

Table 8. Impacts of diesel bus fuel economy on optimal replacement plan (diesel FE 3.32 mpg)

\begin{tabular}{|c|c|c|c|c|c|c|c|c|c|c|c|}
\hline $\begin{array}{l}\text { Diesel FE (mpg) } \\
\text { Hybrid FE: } 3.65 \mathrm{mpg}\end{array}$ & 2.5 & 2.6 & 2.7 & 2.8 & 2.9 & 3.0 & 3.1 & 3.2 & 3.3 & 3.4 & 3.5 \\
\hline $0 \%$ subsidy & $20 \mathrm{D}$ & $20 \mathrm{D}$ & $20 \mathrm{D}$ & $20 \mathrm{D}$ & $20 \mathrm{D}$ & $20 \mathrm{D}$ & $20 \mathrm{D}$ & $20 \mathrm{D}$ & $20 \mathrm{D}$ & $20 \mathrm{D}$ & $20 \mathrm{D}$ \\
\hline $80 \%$ subsidy & $16 \mathrm{H}$ & $16 \mathrm{H}$ & $16 \mathrm{H}$ & $16 \mathrm{H}$ & $16 \mathrm{H}$ & $16 \mathrm{H}$ & $16 \mathrm{H}$ & $16 \mathrm{H}$ & $16 \mathrm{H}$ & $16 \mathrm{H}$ & $16 \mathrm{H}$ \\
\hline $\begin{array}{l}\text { Hybrid FE (mpg) } \\
\text { Diesel FE: } 3.32 \mathrm{mpg}\end{array}$ & 3.15 & 3.25 & 3.35 & 3.45 & 3.55 & 3.65 & 3.75 & 3.85 & 3.95 & 4.05 & 4.15 \\
\hline $0 \%$ subsidy & $20 \mathrm{D}$ & $20 \mathrm{D}$ & $20 \mathrm{D}$ & $20 \mathrm{D}$ & $20 \mathrm{D}$ & $20 \mathrm{D}$ & $20 \mathrm{D}$ & $20 \mathrm{D}$ & $20 \mathrm{D}$ & $20 \mathrm{D}$ & $20 \mathrm{D}$ \\
\hline $80 \%$ subsidy & $17 \mathrm{D}$ & $17 \mathrm{D}$ & $17 \mathrm{D}$ & $16 \mathrm{H}$ & $16 \mathrm{H}$ & $16 \mathrm{H}$ & $16 \mathrm{H}$ & $16 \mathrm{H}$ & $16 \mathrm{H}$ & $16 \mathrm{H}$ & $16 \mathrm{H}$ \\
\hline
\end{tabular}


Table 9. Impacts of diesel bus fuel economy on optimal replacement plan (diesel FE $2.50 \mathrm{mpg}$ )

\begin{tabular}{l|lllllllllll}
\hline $\begin{array}{l}\text { Diesel FE (mpg) } \\
\text { Hybrid FE: } 3.65 \mathrm{mpg}\end{array}$ & 2.0 & 2.1 & 2.2 & 2.3 & 2.4 & 2.5 & 2.6 & 2.7 & 2.8 & 2.9 & 3.0 \\
\hline $\begin{array}{l}\text { 0\% subsidy } \\
80 \% \text { subsidy }\end{array}$ & $20 \mathrm{H}$ & $20 \mathrm{H}$ & $20 \mathrm{H}$ & $20 \mathrm{H}$ & $20 \mathrm{H}$ & $20 \mathrm{D}$ & $20 \mathrm{D}$ & $20 \mathrm{D}$ & $20 \mathrm{D}$ & $20 \mathrm{D}$ & $20 \mathrm{D}$ \\
\hline Hybrid FE (mpg) & $16 \mathrm{H}$ & $16 \mathrm{H}$ & $16 \mathrm{H}$ & $16 \mathrm{H}$ & $16 \mathrm{H}$ & $16 \mathrm{H}$ & $16 \mathrm{H}$ & $16 \mathrm{H}$ & $16 \mathrm{H}$ & $16 \mathrm{H}$ & $16 \mathrm{H}$ \\
Diesel FE: $2.50 \mathrm{mpg}$ & 3.15 & 3.25 & 3.35 & 3.45 & 3.55 & 3.65 & 3.75 & 3.85 & 3.95 & 4.05 & 4.15 \\
\hline $0 \%$ subsidy & $20 \mathrm{D}$ & $20 \mathrm{D}$ & $20 \mathrm{D}$ & $20 \mathrm{D}$ & $20 \mathrm{D}$ & $20 \mathrm{D}$ & $20 \mathrm{D}$ & $20 \mathrm{H}$ & $20 \mathrm{H}$ & $20 \mathrm{H}$ & $20 \mathrm{H}$ \\
$80 \%$ subsidy & $16 \mathrm{H}$ & $16 \mathrm{H}$ & $16 \mathrm{H}$ & $16 \mathrm{H}$ & $16 \mathrm{H}$ & $16 \mathrm{H}$ & $16 \mathrm{H}$ & $16 \mathrm{H}$ & $16 \mathrm{H}$ & $16 \mathrm{H}$ & $16 \mathrm{H}$ \\
\hline \hline
\end{tabular}

\section{Annual utilization}

Historical data provided by King County Metro indicated that the average annual utilization ranges between 28,379 miles and 39,679 miles per bus. Therefore, to investigate whether and how annual utilization affects the optimal replacement solutions, 11 different annual utilizations are tested from 28,379 miles/year/bus to 39,679 miles/year/bus with an equal incremental interval of 1,130 miles/year/bus. Results are shown in Table 10.

Table 10. Impacts of annual utilization on optimal replacement plan (diesel FE $3.32 \mathrm{mpg}$ )

\begin{tabular}{|c|c|c|c|c|c|c|c|c|c|c|c|}
\hline Annual utilization (miles/year/bus) & 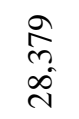 & $\begin{array}{l}\text { gे } \\
\text { ڤn } \\
\text { กे }\end{array}$ & $\begin{array}{l}\text { ले } \\
\text { రీ} \\
\text { లి }\end{array}$ & $\frac{\mathfrak{g}}{\stackrel{m}{m}}$ & $\begin{array}{l}2 \\
\infty \\
\text { त } \\
\text { nి }\end{array}$ & 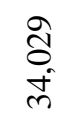 & $\frac{a}{n}$ & $\begin{array}{l}\text { के } \\
\text { ஸे } \\
\text { రీ} \\
\text { లn }\end{array}$ & $\underset{m}{\frac{\sigma}{\sigma}}$ & $\begin{array}{l}\stackrel{a}{+} \\
n \\
\infty \\
n\end{array}$ & 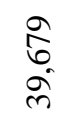 \\
\hline $0 \%$ subsidy & $20 \mathrm{D}$ & $20 \mathrm{D}$ & $20 \mathrm{D}$ & $20 \mathrm{D}$ & $20 \mathrm{D}$ & $20 \mathrm{D}$ & $20 \mathrm{D}$ & $20 \mathrm{D}$ & $20 \mathrm{D}$ & $20 \mathrm{D}$ & $20 \mathrm{D}$ \\
\hline $80 \%$ subsidy & $18 \mathrm{H}$ & $17 \mathrm{H}$ & $17 \mathrm{H}$ & $16 \mathrm{H}$ & $16 \mathrm{H}$ & $16 \mathrm{H}$ & $15 \mathrm{H}$ & $15 \mathrm{H}$ & $15 \mathrm{H}$ & $15 \mathrm{H}$ & $14 \mathrm{H}$ \\
\hline
\end{tabular}

Table 11. Impacts of annual utilization on optimal replacement plan (diesel FE $2.50 \mathrm{mpg}$ )

\begin{tabular}{|c|c|c|c|c|c|c|c|c|c|c|c|}
\hline Annual utilization (miles/year/bus) & $\begin{array}{l}\stackrel{2}{N} \\
\text { no } \\
\infty\end{array}$ & $\begin{array}{l}\text { gे } \\
\text { مू } \\
\text { సे }\end{array}$ & $\begin{array}{l}\hat{n} \\
\hat{n} \\
\hat{n}\end{array}$ & $\underset{m}{\stackrel{a}{2}}$ & $\begin{array}{l}\text { बे } \\
\infty \\
\text { ते }\end{array}$ & $\begin{array}{l}\text { సે } \\
\text { ঠे }\end{array}$ & $\frac{a}{n}$ & 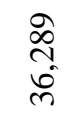 & $\underset{m}{\stackrel{a}{J}}$ & $\begin{array}{l}\hat{+} \\
n \\
\infty \\
n\end{array}$ & $\begin{array}{l}2 \\
\text { a } \\
\text { n. }\end{array}$ \\
\hline $0 \%$ subsidy & 20D & 20D & 20D & 20D & $20 \mathrm{D}$ & 20D & 20D & $20 \mathrm{H}$ & $20 \mathrm{H}$ & $20 \mathrm{H}$ & $20 \mathrm{H}$ \\
\hline $80 \%$ subsidy & $18 \mathrm{H}$ & $17 \mathrm{H}$ & $17 \mathrm{H}$ & $16 \mathrm{H}$ & $16 \mathrm{H}$ & $16 \mathrm{H}$ & $15 \mathrm{H}$ & $15 \mathrm{H}$ & $15 \mathrm{H}$ & $15 \mathrm{H}$ & $14 \mathrm{H}$ \\
\hline
\end{tabular}

Results from Table 10 and Table 11 indicate a general trend that as annual utilization increases hybrid buses are more favorable because savings from fuel and O\&M costs compensate for the higher capital costs. In the $80 \%$ subsidy scenario the optimal solution is always to buy hybrid buses, but the optimal replacement cycle decreases from 18 years to 14 years as annual utilization increases from 28,375 miles per year to 39,679 miles per year. In the $0 \%$ subsidy scenario, the optimal bus choice depends on the annual utilization level and diesel fuel economy. The hybrid bus becomes the best option with utilization levels above 36,000 miles and low diesel fuel economy.

\section{Linear O\&M Costs}

Per-mile O\&M costs as a function of age are the most difficult cost functions to estimate or forecast because of the high variance among buses and the lack of data for older buses (more than 12 years old). Therefore, average values for hybrid and diesel buses are used and linear extrapolations are assumed to predict the per-mile O\&M costs as a function of age. Although the 
historical data has shown a linear behavior so far on the aggregate (see Appendixes A, B, and C) it is essential to ensure that the linearity assumptions hold into the future.

The variance between buses is represented by two additional per-mile O\&M cost functions that are lower and higher than their average functions. As shown in Figure 5 (a) and (b), the solid lines represent the "Mid" functions, which are the baseline per-mile O\&M cost functions. The two dashed lines represent "High" and "Low" per-mile O\&M cost functions. In the sensitivity analysis the intercepts for the three functions are the same for each bus type, but the slopes of "Low" and "High" functions are 10\% lower and higher than their "Mid" per-mile O\&M cost function slopes. This generates nine scenarios. Each of the nine scenarios for each diesel bus fuel economy (18 scenarios total) is tested to investigate the impact of relative permile O\&M cost functions on the optimal replacement solution. Results are shown in Table 12 and Table 13.

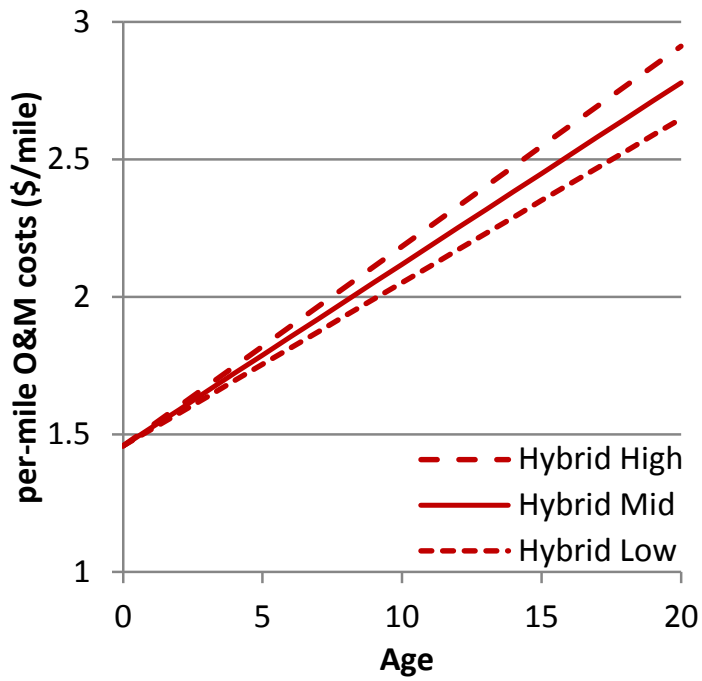

(a) Hybrid bus

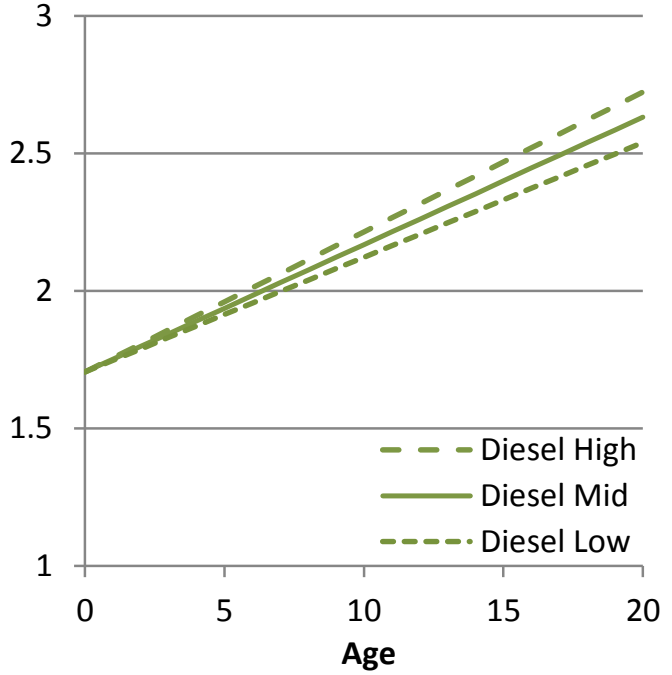

(b) Diesel bus

Figure 5. Per-mile O\&M cost functions

Without subsidies, the optimal replacement solution is to always choose diesel buses and replace them every 20 years except for the one combination of low hybrid O\&M and high diesel per-mile O\&M (for both high and low diesel fuel economy). On the other hand, when the 80\% purchase subsidy is received the optimal candidate is always the hybrid bus and the optimal replacement cycle increases from 15 years to 17 years as the per-mile O\&M cost function slope decreases (negative correlation). The results indicate that within these ranges of per-mile O\&M, the relative slopes affect the optimal bus type choice but not the optimal replacement cycle in the $0 \%$ subsidy scenario. On the other hand, the relative slopes affect the optimal replacement cycle but not the optimal bus type in the $80 \%$ subsidy scenario.

Table 12. Impacts of O\&M cost function slopes (diesel FE 3.32 mpg)

\begin{tabular}{l|lllllllll}
\hline \hline Hybrid slope & High & High & High & Mid & Mid & Mid & Low & Low & Low \\
Diesel slope & Low & Mid & High & Low & Mid & High & Low & Mid & High \\
\hline $0 \%$ subsidy & $20 \mathrm{D}$ & $20 \mathrm{D}$ & $20 \mathrm{D}$ & $20 \mathrm{D}$ & $20 \mathrm{D}$ & $20 \mathrm{D}$ & $20 \mathrm{D}$ & $20 \mathrm{D}$ & $20 \mathrm{H}$ \\
$80 \%$ subsidy & $15 \mathrm{H}$ & $15 \mathrm{H}$ & $15 \mathrm{H}$ & $16 \mathrm{H}$ & $16 \mathrm{H}$ & $16 \mathrm{H}$ & $17 \mathrm{H}$ & $17 \mathrm{H}$ & $17 \mathrm{H}$ \\
\hline \hline
\end{tabular}


Table 13. Impacts of O\&M cost function slopes (diesel FE $2.50 \mathrm{mpg}$ )

\begin{tabular}{l|lllllllll}
\hline \hline Hybrid slope & High & High & High & Mid & Mid & Mid & Low & Low & Low \\
Diesel slope & Low & Mid & High & Low & Mid & High & Low & Mid & High \\
\hline $0 \%$ subsidy & $20 \mathrm{D}$ & $20 \mathrm{D}$ & $20 \mathrm{D}$ & $20 \mathrm{D}$ & $20 \mathrm{D}$ & $20 \mathrm{D}$ & $20 \mathrm{D}$ & $20 \mathrm{D}$ & $20 \mathrm{H}$ \\
$80 \%$ subsidy & $15 \mathrm{H}$ & $15 \mathrm{H}$ & $15 \mathrm{H}$ & $16 \mathrm{H}$ & $16 \mathrm{H}$ & $16 \mathrm{H}$ & $17 \mathrm{H}$ & $17 \mathrm{H}$ & $17 \mathrm{H}$ \\
\hline \hline
\end{tabular}

\section{Non-Linear O\&M Costs}

To test the impact of more concentrated major maintenance costs distributions we follow the distribution curves provided by a FTA report (Laver et al., 2007), which are shown in Figure 6 (unfortunately, there is more information for 40-foot buses). These two additional, combined, nonlinear, per-mile, maintenance cost functions are shown in Figure 7 as the dotted blue and black lines. Only a diesel bus with $3.32 \mathrm{mpg}$ and medium fuel prices is analyzed in this section.

Results indicated that without FTA support, different shapes of maintenance cost functions have no impact on the optimal replacement age. When the 80\% FTA support is applied, the optimal replacement time does change. Diesel bus optimal replacement age varies across different maintenance cost functions. In both cases, the concentrated peaks and optimal replacement ages are close to each other (17 and 13 years, respectively). This indicated that with an $80 \%$ subsidy, it is very important to determine the maintenance cost peaks since they do impact the optimal replacement age.

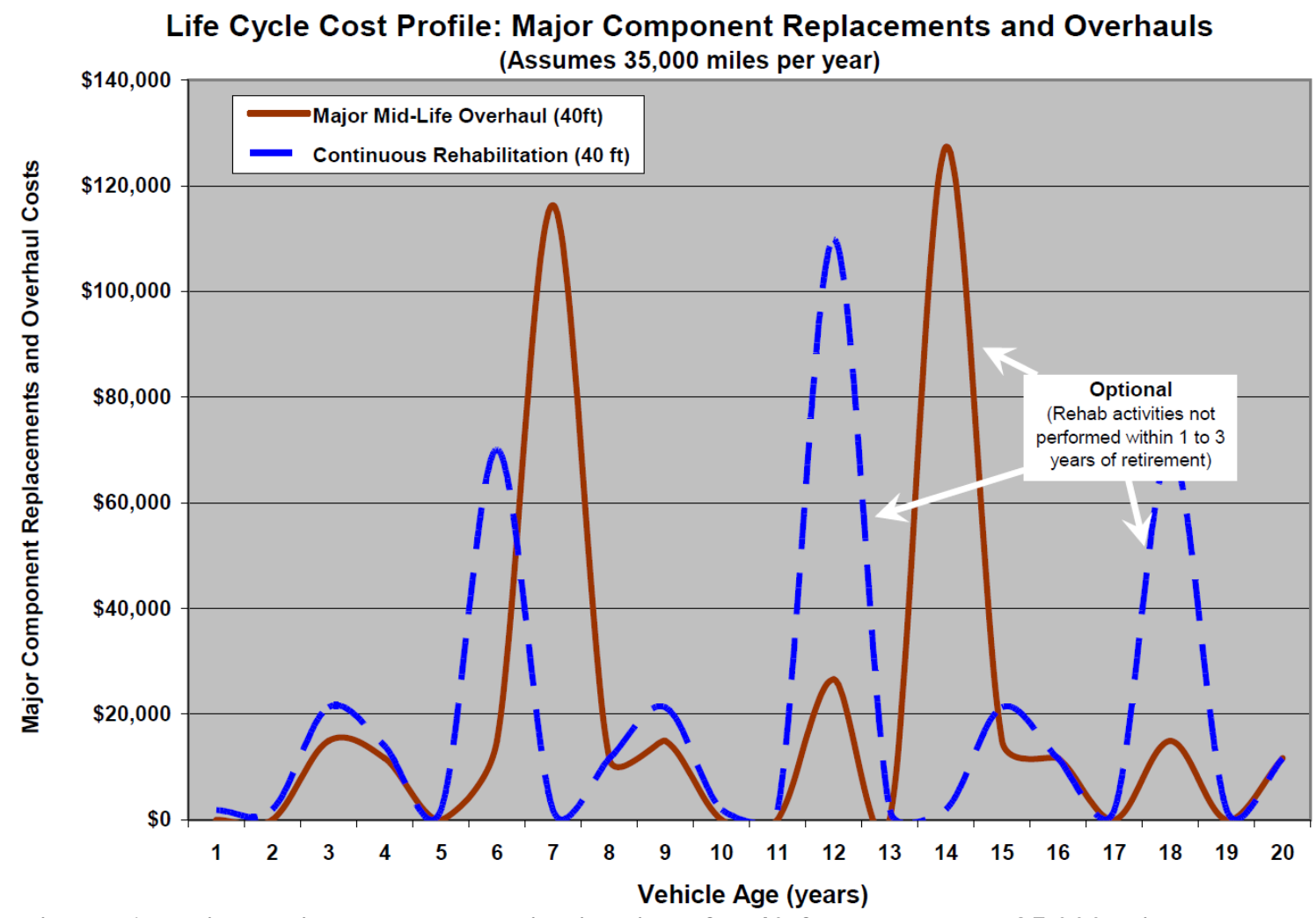

Figure 6. Major maintenance cost distributions for 40-foot buses and 35,000 miles per year utilization

Source: Laver et al., 2007 


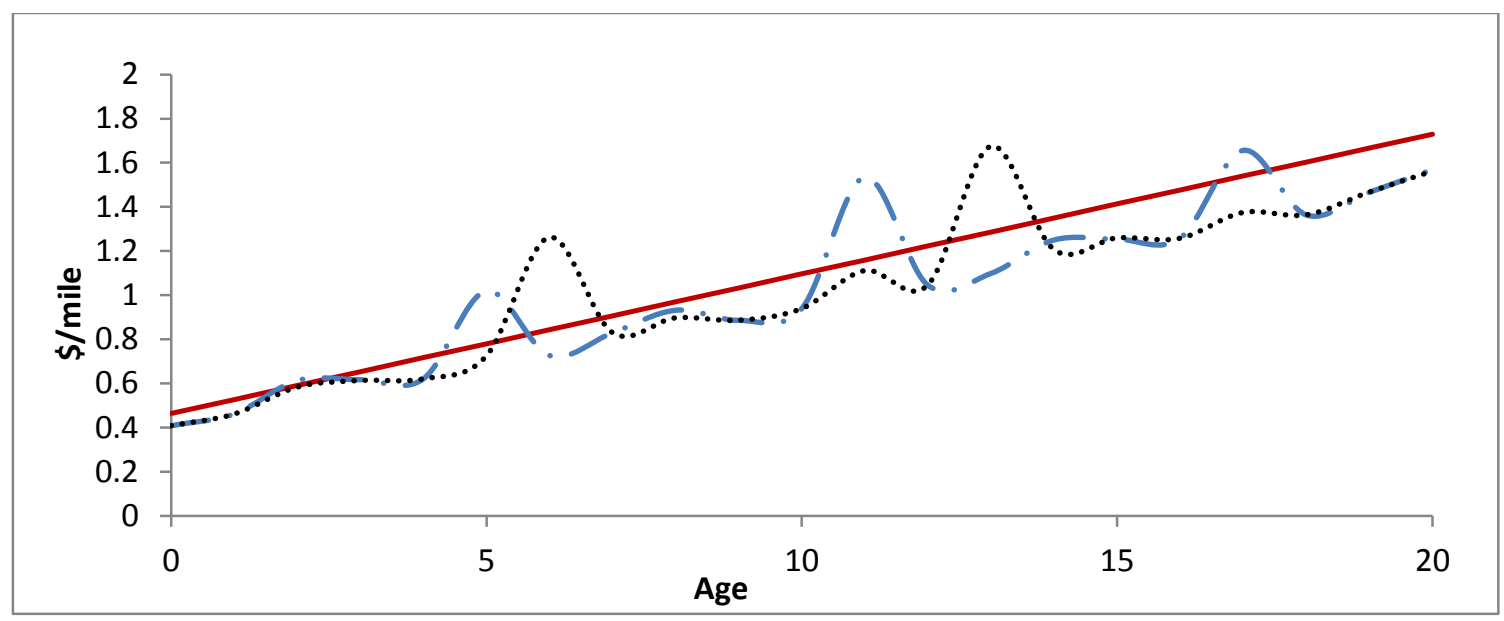

Figure 7. Nonlinear, per-mile, maintenance cost functions

\section{Capital purchase cost}

The capital cost of purchasing new buses may vary due to market fluctuations, technology improvements and purchase quantity. It has also been shown in the baseline scenario results (Table 6) that purchase costs share a large percentage of the total life cycle costs. Therefore, it is necessary to evaluate how sensitive the optimal replacement plan is in response to varying capital purchase costs. Twenty percent under and over the current purchase cost for diesel and hybrid buses is tested, and results are shown in Table 14 and Table 15.

Results are consistent. With no purchase cost subsidy the replacement age is always 20 years, but a $10 \%$ reduction in prices tips the balance. If purchase costs for both hybrid and diesel buses are reduced by at least $10 \%$, hybrid buses are the best choice. With an $80 \%$ subsidy level, the optimal bus is always the hybrid bus but the replacement age is reduced as the purchase price decreases.

Table 14. Impacts of capital purchase cost on optimal replacement plan (diesel FE 3.32 mpg)

\begin{tabular}{l|rrrrrrrrr}
\hline Capital cost percent change & $-20 \%$ & $-15 \%$ & $-10 \%$ & $-5 \%$ & $0 \%$ & $5 \%$ & $10 \%$ & $15 \%$ & $20 \%$ \\
\hline $0 \%$ subsidy & $20 \mathrm{H}$ & $20 \mathrm{H}$ & $20 \mathrm{H}$ & $20 \mathrm{D}$ & $20 \mathrm{D}$ & $20 \mathrm{D}$ & $20 \mathrm{D}$ & $20 \mathrm{D}$ & $20 \mathrm{D}$ \\
$80 \%$ subsidy & $14 \mathrm{H}$ & $15 \mathrm{H}$ & $15 \mathrm{H}$ & $16 \mathrm{H}$ & $16 \mathrm{H}$ & $16 \mathrm{H}$ & $17 \mathrm{H}$ & $18 \mathrm{H}$ & $18 \mathrm{H}$ \\
\hline \hline
\end{tabular}

Table 15. Impacts of capital purchase cost on optimal replacement plan (diesel FE 2.50 mpg)

\begin{tabular}{l|rrrrrrrrr}
\hline Capital cost percent change & $-20 \%$ & $-15 \%$ & $-10 \%$ & $-5 \%$ & $0 \%$ & $5 \%$ & $10 \%$ & $15 \%$ & $20 \%$ \\
\hline $0 \%$ subsidy & $20 \mathrm{H}$ & $20 \mathrm{H}$ & $20 \mathrm{H}$ & $20 \mathrm{D}$ & $20 \mathrm{D}$ & $20 \mathrm{D}$ & $20 \mathrm{D}$ & $20 \mathrm{D}$ & $20 \mathrm{D}$ \\
$80 \%$ subsidy & $14 \mathrm{H}$ & $15 \mathrm{H}$ & $15 \mathrm{H}$ & $16 \mathrm{H}$ & $16 \mathrm{H}$ & $16 \mathrm{H}$ & $17 \mathrm{H}$ & $18 \mathrm{H}$ & $18 \mathrm{H}$ \\
\hline \hline
\end{tabular}

\section{CO2 emissions}

The $\mathrm{CO} 2$ emissions costs are not considered in the baseline scenarios. In order to test whether $\mathrm{CO} 2$ emissions have a significant impact on optimal solutions, a \$30/ton CO2 emissions cost (suggested by King County Metro) was added to the model objective functions. Results are shown in Table 16 and Table 17. Results show that CO2 emissions costs are a small part of total costs in both $0 \%$ and $80 \%$ scenarios. With a $\$ 30 /$ ton $\mathrm{CO} 2$ emissions cost, the optimal bus candidate and replacement cycle are the same as in the baseline scenario where $\mathrm{CO} 2$ emissions 
penalty costs are not considered. Results indicate that this $\mathrm{CO} 2$ emissions cost has no impact on optimal replacement policies.

However, with a $\$ 100 /$ ton CO2 emissions cost plus low diesel FE, it is optimal to buy hybrids with the same replacement cycle as in the baseline scenario where $\mathrm{CO} 2$ emissions penalty costs are not considered. As mentioned later in the breakeven analysis section, a $\$ 60 /$ ton or higher $\mathrm{CO} 2$ emissions cost tips the balance in favor of hybrid buses.

Table 16. First 20-year results after including CO2 emissions costs (diesel FE 3.32 mpg)

\begin{tabular}{|c|c|c|c|c|}
\hline \multirow{2}{*}{$\begin{array}{l}\text { Subsidy } \\
\text { CO2 penalty cost (\$/ton) }\end{array}$} & \multicolumn{2}{|c|}{$0 \%$} & \multicolumn{2}{|c|}{$80 \%$} \\
\hline & 100 & 30 & 100 & 30 \\
\hline \multicolumn{5}{|l|}{ Discounted annualized } \\
\hline Total cost $(\$)$ & 90,371 & 94,027 & 60,072 & 63,410 \\
\hline Purchase cost (\$) & 36,850 & 36,850 & 11,806 & 11,806 \\
\hline Fuel cost (\$) & 19,939 & 19,939 & 18,137 & 18,137 \\
\hline O\&M cost $(\$)$ & 31,992 & 31,992 & 28,710 & 28,710 \\
\hline $\mathrm{CO} 2$ cost $(\$)$ & 1,590 & 5,245 & 1,431 & 4,769 \\
\hline Salvage revenue $(\$)$ & 0 & 0 & -12 & -12 \\
\hline Per-mile net cost $(\$ /$ mile $)$ & 2.735 & 2.845 & 1.818 & 1.919 \\
\hline \multicolumn{5}{|l|}{ Not discounted annualized } \\
\hline Total cost $(\$)$ & 155,757 & 163,358 & 124,675 & 131,614 \\
\hline Purchase cost (\$) & 36,850 & 36,850 & 19,160 & 19,160 \\
\hline Fuel cost $(\$)$ & 44,688 & 44,688 & 40,648 & 40,648 \\
\hline O\&M cost $(\$)$ & 70,915 & 70,915 & 61,943 & 61,943 \\
\hline $\mathrm{CO} 2$ cost $(\$)$ & 3,305 & 10,905 & 2,974 & 9,914 \\
\hline Salvage revenue $(\$)$ & 0 & 0 & -50 & -50 \\
\hline Not discounted per-mile cost $(\$ /$ mile $)$ & 4.713 & 4.943 & 3.773 & 3.983 \\
\hline Fuel (gallons) & 9,953 & 9,953 & 9,053 & 9,053 \\
\hline $\mathrm{CO} 2$ (tons) & 110 & 110 & 100 & 100 \\
\hline Miles & 33,045 & 33,045 & 33,045 & 33,045 \\
\hline Hybrid replacement age & - & - & 16 & 16 \\
\hline Diesel replacement age & 20 & 20 & - & - \\
\hline
\end{tabular}


Table 17. First 20-year results after including CO2 emissions costs (diesel FE $2.50 \mathrm{mpg}$ )

\begin{tabular}{|c|c|c|c|c|}
\hline \multirow{2}{*}{$\begin{array}{l}\text { Subsidy } \\
\mathrm{CO} 2 \text { penalty cost }(\$ / \text { ton })\end{array}$} & \multicolumn{2}{|c|}{$0 \%$} & \multicolumn{2}{|c|}{$80 \%$} \\
\hline & 100 & 30 & 100 & 30 \\
\hline \multicolumn{5}{|l|}{ Discounted annualized } \\
\hline Total cost $(\$)$ & 97,388 & 100,939 & 60,072 & 63,410 \\
\hline Purchase cost (\$) & 36,850 & 47,900 & 11,806 & 11,806 \\
\hline Fuel cost (\$) & 26,480 & 18,137 & 18,137 & 18,137 \\
\hline O\&M cost $(\$)$ & 31,992 & 30,134 & 28,710 & 28,710 \\
\hline $\mathrm{CO} 2$ cost $(\$)$ & 2,066 & 4,769 & 1,431 & 4,769 \\
\hline Salvage revenue $(\$)$ & 0 & 0 & -12 & -12 \\
\hline Per-mile net cost $(\$ /$ mile $)$ & 2.947 & 3.055 & 1.818 & 1.919 \\
\hline \multicolumn{5}{|l|}{ Not discounted annualized } \\
\hline Total cost $(\$)$ & 171,406 & 167,393 & 124,675 & 131,614 \\
\hline Purchase cost (\$) & 36,850 & 47,900 & 19,160 & 19,160 \\
\hline Fuel cost $(\$)$ & 59,346 & 40,648 & 40,648 & 40,648 \\
\hline O\&M cost $(\$)$ & 70,915 & 68,932 & 61,943 & 61,943 \\
\hline $\mathrm{CO} 2 \operatorname{cost}(\$)$ & 4,296 & 9,914 & 2,974 & 9,914 \\
\hline Salvage revenue $(\$)$ & 0 & -50 & 0 & -50 \\
\hline Not discounted per-mile cost (\$/mile) & 5.187 & 5.066 & 3.773 & 3.983 \\
\hline Fuel (gallons) & 13,218 & 9,053 & 9,053 & 9,053 \\
\hline $\mathrm{CO} 2$ (tons) & 147 & 100 & 100 & 100 \\
\hline Miles & 33,045 & 33,045 & 33,045 & 33,045 \\
\hline Hybrid replacement age & - & 20 & 16 & 16 \\
\hline Diesel replacement age & 20 & - & - & - \\
\hline
\end{tabular}

\section{Initial age and bus type}

The baseline scenarios assume that there are no existing buses. However, it is interesting to evaluate scenarios with an existing fleet of buses of different ages. Scenarios with different initial fleet compositions (types and ages) are also tested. The initial fleet composition is assumed to be one bus, hybrid or diesel bus, with any of the following six ages: 3, 6, 9, 12, 15, and 18. Results for the 24 scenarios are shown in Table 18 and Table 19.

Results indicate that initial age has little impact on replacement age or optimal bus type. In the $80 \%$ subsidy scenario, if the initial bus is a hybrid, the optimal solution will be to keep using the hybrid bus and replace it every 16 years. If the initial bus is diesel, the optimal solution will be to keep using the diesel bus until it reaches age 12 (or age 15 or 18 if the initial diesel bus age is already 15 or 18), and then replace it with a hybrid bus every 16 years in all future years in the time horizon. In the $80 \%$ subsidy case, the optimal bus is the hybrid; even if the initial bus is a diesel, there is always a reversion towards the optimal policy. In the $0 \%$ subsidy scenario the opposite takes place. 
Table 18. Impacts of initial fleet composition on optimal replacement plan (80\% subsidy)

\begin{tabular}{l|llllll|llllll}
\hline \hline Diesel FE (mpg) & \multicolumn{6}{|c|}{$2.50 \mathrm{mpg}$} & \multicolumn{7}{c}{$3.32 \mathrm{mpg}$} \\
Initial bus age (Hybrid) & 3 & 6 & 9 & 12 & 15 & 18 & 3 & 6 & 9 & 12 & 15 & 18 \\
\hline Hybrid replacement age & 16 & 16 & 16 & 16 & 16 & 18 & 16 & 16 & 16 & 16 & 16 & 18 \\
Diesel replacement age & - & - & - & - & - & - & - & - & - & - & - & - \\
\hline Initial bus age (Diesel) & 3 & 6 & 9 & 12 & 15 & 18 & 3 & 6 & 9 & 12 & 15 & 18 \\
\hline Hybrid replacement age & 16 & 16 & 16 & 16 & 16 & 18 & 16 & 16 & 16 & 16 & 16 & 18 \\
Diesel replacement age & 12 & 12 & 12 & 12 & 15 & 18 & 15 & 15 & 15 & 15 & 15 & 18 \\
\hline \hline
\end{tabular}

(in italics a one-time replacement)

Table 19. Impacts of initial fleet configuration on optimal replacement plan ( $0 \%$ subsidy)

\begin{tabular}{l|llllll|lllllll}
\hline \hline Diesel FE (mpg) & \multicolumn{7}{|c|}{$2.50 \mathrm{mpg}$} & \multicolumn{7}{c}{$3.32 \mathrm{mpg}$} \\
Initial bus age (Hybrid) & 3 & 6 & 9 & 12 & 15 & 18 & 3 & 6 & 9 & 12 & 15 & 18 \\
\hline Hybrid replacement age & 20 & 20 & 20 & 20 & 20 & 20 & 20 & 20 & 20 & 20 & 20 & 20 \\
Diesel replacement age & 20 & 20 & 20 & 20 & 20 & 20 & 20 & 20 & 20 & 20 & 20 & 20 \\
\hline Initial bus age (Diesel) & 3 & 6 & 9 & 12 & 15 & 18 & 3 & 6 & 9 & 12 & 15 & 18 \\
\hline Hybrid replacement age & - & - & - & - & - & - & - & - & - & - & - & - \\
Diesel replacement age & 20 & 20 & 20 & 20 & 20 & 20 & 20 & 20 & 20 & 20 & 20 & 20 \\
\hline \hline
\end{tabular}

(in italics a one-time replacement)

\section{Elasticity}

The previous section focuses on the impacts of fuel economy, annual utilization, O\&M costs, capital purchase costs, $\mathrm{CO} 2$ emissions costs and initial age and bus type on the optimal replacement plan. It is also necessary to analyze which input variable has the highest impact on the optimal per-mile net cost. Elasticity of per-mile net cost to each of the above input factors was calculated according to formula 12.

Elasticity values for the cost per miles are summarized in Table 20. For example, with an annual utilization range between 28,379 miles/year/bus and 39,679 miles/year/bus, each additional $1 \%$ increase in annual utilization decreases $0.41 \%$ per-mile net cost $(0 \%$ subsidy scenario) or decreases $0.17 \%$ ( $80 \%$ subsidy scenario). Results show that a nominal annual discount rate and a utilization rate have the highest absolute cost-per-mile elasticity values. Elasticity values for the Net Present Value (NPV) are summarized in Table 21. For example, with an annual utilization range between 28,379 miles/year/bus and 39,679 miles/year/bus, each additional $1 \%$ increase in annual utilization increases the NPV $0.59 \%$ per-mile net cost ( $0 \%$ subsidy scenario) and $0.78 \%$ (80\% subsidy scenario). Results show that annual utilization, nominal annual discount rate, and vehicle purchase price have the highest absolute NPV elasticity values.

An elasticity value is significant when the output variable changes significantly (in this case, the output variables are cost per mile and net present value). 
Table 20. Elasticity between various input variables and per-mile net cost (diesel $3.32 \mathrm{mpg}$ )

\begin{tabular}{|c|c|c|}
\hline Factors & $0 \%$ subsidy & $80 \%$ subsidy \\
\hline Vehicle Factors & & \\
\hline $\begin{array}{l}\text { Diesel bus mpg } \\
(2.5-3.3)\end{array}$ & -0.24 & 0.00 \\
\hline $\begin{array}{l}\text { Hybrid bus mpg } \\
(3.15-4.15)\end{array}$ & 0.00 & -0.26 \\
\hline $\begin{array}{l}\text { Diesel bus O\&M cost function slope } \\
(\$ 0.0417 / \mathrm{mi} / \text { year }-\$ 0.0509 / \mathrm{mi} / \text { year })\end{array}$ & 0.06 & 0.00 \\
\hline $\begin{array}{l}\text { Hybrid bus O\&M cost function slope } \\
(\$ 0.0595 / \mathrm{mi} / \text { year }-\$ 0.0727 / \mathrm{mi} / \text { year })\end{array}$ & 0.00 & 0.09 \\
\hline $\begin{array}{l}\text { Diesel bus price } \\
(\$ 589,600-\$ 737,000)\end{array}$ & 0.38 & 0.00 \\
\hline $\begin{array}{l}\text { Hybrid bus price } \\
(\$ 766,400-\$ 958,000)\end{array}$ & 0.13 & 0.17 \\
\hline \multicolumn{3}{|l|}{ General Factors } \\
\hline $\begin{array}{l}\text { Annual utilization } \\
(28,379 \text { miles/year - } 39,679 \text { miles/year })\end{array}$ & -0.41 & -0.17 \\
\hline $\begin{array}{l}\text { CO2 emissions penalty cost } \\
(\$ 0 / \text { ton }-\$ 100 / \text { ton })\end{array}$ & 0.03 & 0.03 \\
\hline $\begin{array}{l}\text { Fuel price } \\
\text { (\$2.64/gallon }-\$ 4.46 / \text { gallon })\end{array}$ & 0.25 & 0.35 \\
\hline $\begin{array}{l}\text { Fuel inflation rate } \\
(0 \%-5 \%)\end{array}$ & 0.09 & 0.13 \\
\hline $\begin{array}{l}\text { Nominal annual discount rate } \\
(5 \%-15 \%)\end{array}$ & -0.85 & -1.01 \\
\hline
\end{tabular}


Table 21. Elasticity between various input variables and 20-year NPV (diesel $2.50 \mathrm{mpg}$ )

\begin{tabular}{|c|c|c|}
\hline Factors & $0 \%$ subsidy & $80 \%$ subsidy \\
\hline Vehicle Factors & & \\
\hline $\begin{array}{l}\text { Diesel bus mpg } \\
(2.0-3.0)\end{array}$ & 0.00 & -0.16 \\
\hline $\begin{array}{l}\text { Hybrid bus mpg } \\
(3.15-4.15)\end{array}$ & -0.05 & -0.31 \\
\hline $\begin{array}{l}\text { Diesel bus O\&M cost function slope } \\
(\$ 0.0417 / \mathrm{mi} / \text { year }-\$ 0.0509 / \mathrm{mi} / \text { year })\end{array}$ & 0.01 & 0.02 \\
\hline $\begin{array}{l}\text { Hybrid bus O\&M cost function slope } \\
\text { ( } \$ 0.0595 / \mathrm{mi} / \text { year }-\$ 0.0727 / \mathrm{mi} / \text { year })\end{array}$ & 0.01 & 0.03 \\
\hline $\begin{array}{l}\text { Diesel bus price } \\
(\$ 589,600-\$ 737,000)\end{array}$ & 0.36 & 0.00 \\
\hline $\begin{array}{l}\text { Hybrid bus price } \\
(\$ 766,400-\$ 958,000)\end{array}$ & 0.43 & 0.21 \\
\hline General Factors & & \\
\hline $\begin{array}{l}\text { Annual utilization } \\
(28,379 \text { miles/year }-39,679 \text { miles/year })\end{array}$ & 0.59 & 0.78 \\
\hline $\begin{array}{l}\text { CO2 emissions penalty cost } \\
(\$ 0 / \text { ton }-\$ 30 / \text { ton })\end{array}$ & 0.01 & 0.01 \\
\hline $\begin{array}{l}\text { Fuel price } \\
\text { (\$2.64/gallon }-\$ 4.46 / \text { gallon })\end{array}$ & 0.25 & 0.31 \\
\hline $\begin{array}{l}\text { Fuel inflation rate } \\
(0 \%-5 \%)\end{array}$ & 0.05 & 0.06 \\
\hline $\begin{array}{l}\text { Nominal annual discount rate } \\
(5 \%-15 \%)\end{array}$ & -0.38 & -0.55 \\
\hline
\end{tabular}

\section{Breakeven analysis}

With an $80 \%$ FTA subsidy the best policy is to buy hybrid buses. However, there is a breakeven value for each subsidy level and a combination fuel price-diesel FE. The breakeven subsidy values are calculated for the three fuel price scenarios and two diesel fuel efficiencies. Results are shown in Table 22 and Table 23. For example, with the mid fuel price forecast functions (initial value $\$ 3.48 / \mathrm{gal}$ ), it is more economical to buy a hybrid bus if the purchase cost subsidy is more than $7 \%$ and the diesel bus fuel economy is $2.50 \mathrm{mpg}$. It is more economical to buy a diesel bus if the subsidy is less than $7 \%$, with all other variables held constant as in the baseline scenario. Results show that higher fuel prices favor the hybrid bus and, therefore, fewer subsidies are required to break even, especially if the diesel fuel economy is low. When the fuel price is $\$ 4.46 /$ gallon and diesel FE is $2.50 \mathrm{mpg}$, even without a subsidy the hybrid bus is the best option.

Since diesel buses are the best option without the government subsidy, the breakeven values in Table 24 and Table 25 indicate what condition or value must be reached. For example, with $0 \%$ subsidy, if the diesel bus fuel economy is less than or equal to $2.43 \mathrm{mpg}$ compared to the hybrid bus baseline fuel economy of $3.65 \mathrm{mpg}$, the optimal solution will be to choose the hybrid bus. If the bus annual utilization is higher than 35,794 miles/year/bus, it will be cost effective to adopt hybrid buses. All of these breakeven values are also consistent with the findings shown in previous subsections. These breakeven values are not too far from the baseline 
values, indicating that the two bus technologies are very competitive without a government subsidy.

Table 22. Breakeven values of government subsidies (diesel FE $3.32 \mathrm{mpg}$ )

\begin{tabular}{l|lll}
\hline \hline fuel price (\$/gallon) & 2.64 & 3.48 & 4.46 \\
\hline subsidy breakeven value & $72 \%$ & $69 \%$ & $66 \%$ \\
\hline \hline
\end{tabular}

Table 23. Breakeven values of government subsidies (diesel FE $2.50 \mathrm{mpg}$ )

\begin{tabular}{l|rrr}
\hline \hline fuel price (\$/gallon) & 2.64 & 3.48 & 4.46 \\
\hline subsidy breakeven value & $26 \%$ & $7 \%$ & $0 \%$ \\
\hline \hline
\end{tabular}

Table 24. Breakeven values for $0 \%$ subsidy scenario (diesel FE $3.32 \mathrm{mpg}$ )

\begin{tabular}{ll|l}
\hline \hline Factors & Baseline values & Breakeven values \\
\hline Vehicular factors & & $\leq 2.43$ \\
Diesel bus mpg & 3.32 & $\geq 6.16$ \\
Hybrid bus mpg & 3.65 & $\geq 0.1155$ \\
Diesel bus per-mile O\&M cost function slope & 0.0436 & $\leq$ inf. \\
Hybrid bus per-mile O\&M cost function slope & 0.0661 & $\geq 882,784$ \\
Diesel bus purchase cost (\$) & 737,000 & $\leq 812,215$ \\
Hybrid bus purchase cost (\$) & 958,000 & $\geq 97,093$ \\
\hline General factors & & $\geq 17.88$ \\
Annual utilization (miles/bus) & 33,045 & $\geq 20.9 \%$ \\
Fuel price (\$/gal) & 3.48 & $\leq 106$ \\
Fuel inflation rate & $2.6 \%$ & $\geq$ inf. \\
CO2 emissions penalty cost (\$/ton) & 0 & $\geq .55 \%$ \\
Nominal annual discount rate & 100 & inf. \\
Planning time horizon (years) & \\
\hline \hline inf. means infeasible, there is no realistic value of the parameter that can change the optimal \\
Solution
\end{tabular}


Table 25. Breakeven values for $0 \%$ subsidy scenario (diesel FE $2.50 \mathrm{mpg}$ )

\begin{tabular}{ll|l}
\hline \hline Factors & Baseline values & Breakeven values \\
\hline Vehicular factors & & \\
Diesel bus mpg & 2.5 & $\leq 2.43$ \\
Hybrid bus mpg & 3.65 & $\geq 3.83$ \\
Diesel bus per-mile O\&M cost function slope & 0.0436 & $\geq 0.0543$ \\
Hybrid bus per-mile O\&M cost function slope & 0.0661 & $\leq 0.058$ \\
Diesel bus purchase cost (\$) & 737,000 & $\geq 753,972$ \\
Hybrid bus purchase cost (\$) & 958,000 & $\leq 941,028$ \\
\hline General factors & & \\
Annual utilization (miles/bus) & 33,045 & $\geq 35,794$ \\
Fuel price (\$/gal) & 3.48 & $\geq 3.83$ \\
Fuel inflation rate & $2.6 \%$ & $\geq 4 \%$ \\
CO2 emissions penalty cost (\$/ton) & 0 & $\geq 60$ \\
Nominal annual discount rate & $9.55 \%$ & $\leq .22 \%$ \\
Planning time horizon (years) & 100 & $\geq$ inf. \\
\hline \hline
\end{tabular}

Table 26. Breakeven values for $80 \%$ subsidy support scenario (diesel FE 3.32 mpg)

\begin{tabular}{ll|l}
\hline Factors & Baseline values & Breakeven values \\
\hline Vehicular factors & & \\
Diesel bus mpg & 3.32 & $\geq 3.60$ \\
Hybrid bus mpg & 3.65 & $\leq 3.36$ \\
Diesel bus per-mile O\&M cost function slope & 0.0436 & $\leq 0.0299$ \\
Hybrid bus per-mile O\&M cost function slope & 0.0661 & $\geq 0.0852$ \\
Diesel bus purchase cost (\$) & 737,000 & $\leq 593,075$ \\
Hybrid bus purchase cost (\$) & 958,000 & $\geq 1,107,625$ \\
\hline General factors & & $\leq 19,418$ \\
Annual utilization (miles/bus) & 33,045 & $\leq$ inf. \\
Fuel price (\$/gal) & 3.48 & $\leq$ inf. \\
Fuel inflation rate & $2.6 \%$ & $\leq$ inf. \\
CO2 emissions penalty cost (\$/ton) & 0 & $\geq 27.25 \%$ \\
Nominal annual discount rate & $9.55 \%$ & $\leq 2$ \\
Planning time horizon (years) & 100 & \\
\hline \hline
\end{tabular}


Table 27. Breakeven values for $80 \%$ subsidy support scenario (diesel FE $2.50 \mathrm{mpg}$ )

\begin{tabular}{ll|l}
\hline Factors & Baseline values & Breakeven values \\
\hline Vehicular factors & & \\
Diesel bus mpg & 2.5 & $\geq 3.59$ \\
Hybrid bus mpg & 3.65 & $\leq 2.52$ \\
Diesel bus per-mile O\&M cost function slope & 0.0436 & $\leq$ inf. \\
Hybrid bus per-mile O\&M cost function slope & 0.0661 & $\geq 0.1724$ \\
Diesel bus purchase cost (\$) & 737,000 & $\leq 106,193$ \\
Hybrid bus purchase cost (\$) & 958,000 & $\geq 1,724,808$ \\
\hline General factors & & \\
Annual utilization (miles/bus) & 33,045 & $\leq$ inf. \\
Fuel price (\$/gal) & 3.48 & $\leq$ inf. \\
Fuel inflation rate & $2.6 \%$ & $\leq$ inf. \\
CO2 emissions penalty cost (\$/ton) & 0 & $\leq$ inf. \\
Nominal annual discount rate & $9.55 \%$ & $\geq$ inf. \\
Planning time horizon (years) & 100 & $\leq$ inf. \\
\hline \hline
\end{tabular}

As shown in Table 26 and Table 27, with an $80 \%$ subsidy the hybrid bus easily dominates and the breakeven values are hard to achieve or are mostly unrealistic. For example, diesel bus fuel economy should be greater than $3.59 \mathrm{mpg}$ when the hybrid bus fuel economy is $3.65 \mathrm{mpg}$. If the annual utilization is less than 19,418 miles/year/bus (unrealistically low), it will be cost effective to adopt diesel buses. Even if the fuel price is as low as 0 , the diesel bus will not be chosen in the optimal solution. These results indicate that hybrid buses clearly outperform diesel buses if an $80 \%$ subsidy can be received. The breakeven values above indicate to what extent each factor itself can change optimal vehicle type. When breakeven values are unrealistic or infeasible, the optimal solution for this scenario is highly stable and robust (in this case $80 \%$ subsidy level and $2.50 \mathrm{mpg}$ diesel $\mathrm{FE}$ ). 


\subsection{CONCLUSIONS}

Budget-constrained transit agencies have challenges to minimize total fleet costs. Despite the complexities of bus fleet costs and characteristics, federal bus policies and market factors, bus replacement modeling is shown to be an effective tool to ascertain market and fleet changes on costs and bus replacement timing.

Changing vehicle prices, utilization levels, and operations and maintenance costs have been shown to not only change total per mile costs of fleet operation, but also change the optimal age of bus replacement decisions. Decreases in purchase costs had the greatest impact on the optimal replacement age, which speaks to the importance or even the necessity of transit agencies to receive FTA's bus purchase subsidy. Diesel prices and internalizing $\mathrm{CO}_{2}$ emissions costs have significant impacts on total costs but not on replacement ages. Road calls were shown to have an insignificant impact on total costs. It was also found that early bus replacement, relative to the optimal replacement decision, is more expensive in economic terms than tardy replacement. However, as agencies delay bus replacement, they decrease $\mathrm{CO}_{2}$ emissions because of less frequent emissions costs associated with manufacturing. In addition, elasticities are useful to understand how changes in market and fleet conditions impact replacement age and costs. For example, an increase in bus maintenance costs has a greater impact on total per mile costs relative to higher gas prices.

The case study of hybrid diesel vs. conventional diesel indicates that the bus purchase cost subsidy has a significant impact on optimal bus type choice and its replacement age. Without a purchase cost subsidy, the optimal solution is to choose diesel buses and replace them every 20 years. Sensitivity and breakeven analyses results indicate that the optimal solution is not sensitive to any of the input parameters within the evaluated ranges except when the relative purchase cost difference between diesel and hybrid bus is larger than $10 \%$. With the maximum purchase cost subsidy allowed in the USA (80\%), the optimal solution is to choose hybrid buses and replace them every 14 years. In addition, in the $80 \%$ subsidy case the optimal solution is more sensitive to input parameters. Several findings from the sensitivity and breakeven analyses include: 1) when the base-year fuel price is less than $\$ 2.79 / \mathrm{gal}$, or hybrid bus fuel economy is more than $35 \%$ higher than the diesel bus, the optimal solution is the diesel bus; 2) annual utilization, annual discount rate, fuel inflation rate and $\mathrm{CO} 2$ emissions penalty cost have no impact on the optimal solution within realistic ranges; and 3) higher utilizations or hybrid bus purchase cost decreases with optimal replacement ages from 15 years to 12 years. The breakeven value of the government subsidy indicates that hybrid buses will not be selected by optimal policies unless the subsidy is equal to or greater than $63 \%$, holding all other input parameters constant.

Although the models are general and can be applied to any transit agency, the data utilized is valid for King County Metro and the years of data provided (11 years of data for fleet 23 and seven years of data for fleets 26 and 28). King County Transit, or any agency that wants to make fleet replacement decisions, must annually update fuel price forecasts, utilization, fuel economy, and maintenance cost data records and forecasts. Hybrid and diesel bus fuel economy must be 
representative of the type of route and operating conditions. A wide range of fuel economies was observed in the historical data.

It is particularly important to keep track or forecast major maintenance cost distributions and their peaks. The following codes were detected: engine system, transmission, exhaust system, climate control and hybrid propulsion; however, more codes may appear in the future. Similarly, the validity of linear functions to predict future operating and maintenance costs must be supported by maintenance cost records, company experience, and the schedule of preventive maintenance jobs. Finally, it must be said that presented models are valid to compare bus technologies of similar capacity and performance (e.g., 60-foot buses that are hybrid diesel, conventional diesel, etc.), but not to compare 60- and 40-foot buses even if they share the same technology (e.g., conventional diesel). 


\subsection{REFERENCES}

Bellman, R. Equipment replacement policy. Journal of the Society for Industrial and Applied Mathematics, Vol. 3, 1955, pp. 133-136.

Boudart, J., Figliozzi, M., A Model and Study of the Key Variables Affecting Bus Replacement Age and Lifecycle Costs, 2012, Transportation Research Record 2274, pp 109-113.

DeCicco, J. M. and Thomas, M. A Method for Green Rating of Automobiles. Journal of Industrial Ecology. Vol. 3, No. 1, 1999, pp. 55-75.

Davis, S. C., Diegal, S. W., and Boundy, R, G. Transportation Energy Data Book: Edition 28,U.S. Department of Energy. pp. Table 2.12. ORNL-6984 (Edition 28 of ORNL-5198), 2009.

DOL, 2011, U.S. Department of Labor. CPI Inflation Calculator. BLS, http://www.bls.gov/data/inflation_calculator.htm. Accessed April 25th, 2011.

EPA, 2011, Emission Facts: Average Carbon Dioxide Emissions Resulting from Gasoline and Diesel Fuel. Environmental Protection Agency. Updated April 12th, 2011 http://www.epa.gov/oms/climate/420f05001.htm. Accessed April 21st, 2011.

Figliozzi, M.A, Boudart, J., and Feng, W., Economic and Environmental Optimization of Vehicle Fleets: A Case Study of the Impacts of Policy, Market, Utilization, and Technological Factors, 2011, Transportation Research Record 2252, p. 1-6.

FTA, 1992, Public Transportation in the US: Performance and Condition. A Report To Congress Presented To 49 USC 308. FTA, U.S. Department of Transportation.

Karabakal, N., Lohmann, J. R., and Bean, J. C. Parallel Replacement under Capital Rationing Constraints. Management Science, 1994, pp. 305-319.

KCT, 2011, King County. Conference Call with King County Fleet Manager Ralph McQuillan, Gary Prince, Kurtis McCoy, Eric Hesse

KCTB, 2011, King County Trolley Bus Evaluation, King County Metro, May 2011.

KCMT, 2008, Regional Transit Committee. Service Facility Guidelines. King County Metro Service Development. King County Metro Transit.

Keles, Pinar and Hartman Joseph. Case Study: Bus Fleet Replacement. The Engineering Economist, 49: 253-278, 2004.

Khasnabis, S. M., Bartus, J., and Ellis, R. Asset Management Framework for State Departments of Transportation to Meet Transit Fleet Requirements. Transportation Research Record: Journal of the Transportation Research Board, No. 1835, Transportation Research Board of the National Academies, Washington, D.C., 2003, pp. 74-83.

Kim, H. C., Keoleian, G. A., Grande, D. E., and Bean, J. C. Life Cycle Optimization of Automobile Replacement: Model and Application. Environmental Science \& Technology, Vol. 37, No. 23, 2003, pp. 5407-5413.

Laver, R., Schneck, D., Skorupski, D., Brady, S., Cham, L., and Hamilton, B. A. Useful Life of Transit Buses and Vans. Report No. FTA VA-26-7229-07.1. FTA, U.S. Department of Transportation, 2007.

Linwood, 2011, Linwood Capital LLC. Diesel Fuel Price Forecast. March 3rd, 2011. 
Maclean, H. L. and Lave, L. B. Life Cycle Assessment of Automobile/Fuel Options. Environmental Science Technology. Vol. 37, 2003, pp 5445-5452.

Peet, K., Partridge, E., Hale, M., and Le, P, D. Future Fleets: An Applied Model for Bus Fleet Planning Based on Energy Costs and Impacts. CD-ROM. Transportation Research Board of the National Academies, Washington, D.C., 2010, pp. 1-16.

Rees, L. P., Clayton, E. R., and Taylor, B. W. Network Simulation Model for Police Patrol Vehicle Maintenance and Replacement Analysis. Computers, Environment and Urban Systems, Vol. 7, No. 3, 1982, pp. 191-196.

Samaras, C. and Meisterling, K. Life Cycle Assessment of Greenhouse Gas Emissions from Plug-In Hybrid Vehicles: Implications for Policy. Environment Science Technology, Vol. 42, 2008, pp. 3170-31

Stern, N. The Economics of Climate Change. The Stern Review. Her Majesty's Treasury, United Kingdom, 2006. 76.

Tol, R. The Marginal Costs of Carbon Dioxide Emissions: An Assessment of the Uncertainties. Energy Policy, Vol. 33, 2005, pp.2064-2074.

USA Today, 2011, Vehicles Keep Inching Up and Putting on Pounds. Written on 7/16/2007. Accessed February, 2011.

USDOT, 1997, Departmental Guidance on the Evaluation of Travel Time in Economic Analysis. memo, U.S. Department of Transportation. Used in STEAM software (www.ota.fhwa.dot.gov/steam), 1997.

Wayne, S. W., Sandoval, J. A., and Clark, N. N. Emissions Benefits from Alternative Fuels and Advanced Technology in the U.S. Transit Bus Fleet. Energy and Environment, Vol. 20, No. 4, 2009, pp. 497-515. 



\section{GOTREC \\ AND EDUCATION CONSORTIUM}

P.O. Box 751

Portland, OR 97207

OTREC is dedicated to stimulating and conducting collaborative multi-disciplinary research on multi-modal surface transportation issues, educating a diverse array of current practitioners and future leaders in the transportation field, and encouraging implementation of relevant research results. 